\title{
Access to the Justices' Papers: A Better Balance ${ }^{\star}$
}

\author{
Susan David deMaine ${ }^{\star \star}$
}

But the Constitution does not belong to judges, as a mystery intelligible only to a priestly caste, and it does not belong to political activists, as a set of incendiary talking points. It belongs to the people. It is our responsibility to judge the Court, and it is our judgment that must be decisive in the end. ${ }^{1}$

This article explores the history of Supreme Court Justices' papers and their status as private property. It discusses questions of access, the public's interest in understanding the Court and its decisions, and the effect of the Justices' papers on scholarship and popular research. Several options for encouraging greater openness are proposed.

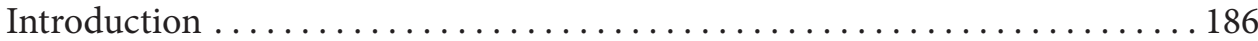

The Problem: Justices Set the Rules on Access to Their Working Papers . . . . . 187

The Public's Interest in Accessing Justices' Papers . . . . . . . . . . . . . 193

Nature and Power of the Court. . . . . . . . . . . . . . . . . . . . . . . 193

Differential Treatment .................................... 196

Effect of Access to Justices' Papers on Scholarship and Knowledge . . . . . . 199

Privacy Interests . . . . . . . . . . . . . . . . . . . 202

* (C) 2018, Susan David deMaine. This article is the product of research funded by the American Association of Law Libraries and LexisNexis, and I am very grateful for their support. I am also deeply indebted to my colleague Benjamin J. Keele. Without his insight, research, and editing, this project would not have come to fruition. Thanks also to Jessica Dickinson for her extensive research, Rena Seidler for her patient editing, and the members of the 2016 Boulder Conference for Legal Information, particularly Maria Protti, for their thoughtful comments. Finally, many thanks to the librarians and archivists at the libraries holding the collections listed in the appendix for their efforts, usually successful, to unearth information regarding original restrictions on the gifted or bequeathed collections.

This article is accompanied by a dataset containing information, current as of September 2017, about all known extant collections of Supreme Court Justices' papers, available at http://hdl .handle.net/1805/14462 [https://perma.cc/8CZ7-7CMS]. A comprehensive collection of this data was last undertaken in 1985 by Alexandra K. Wigdor. See Alexandra K. Wigdor, The Personal Papers of Supreme Court Justices (1985). After an initial collection of available data, I contacted the holder of the largest collection for each Justice, requesting further information on restrictions placed on the gift or bequest. This generated a response rate of sixty-six percent. Direct phone calls increased that response rate to over ninety percent. Public universities were the most responsive institutions; many were willing to share copies of donor agreements and wills. Other institutions have policies that do not allow such sharing of what is deemed private information. The appendix tabulates these restrictions.

** Assistant Director for Information Services, Ruth Lilly Law Library, Indiana University Robert H. McKinney School of Law.

1. Kermit Roosevelt III, The Myth of Judicial Activism: Making Sense of Supreme Court DECISIONS 7 (2006). 


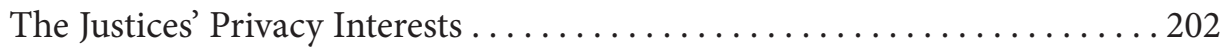

Supreme Court Clerks' Privacy Interests . . . . . . . . . . . . . . . 206

Shifting From Privacy to Public Policy . . . . . . . . . . . . . . . . . . . . 207

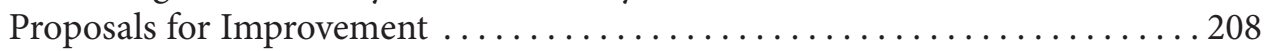

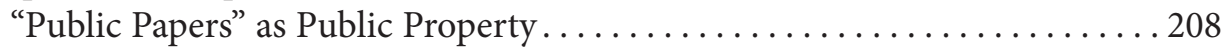

Congress Changes Ownership Status Only; Judicial Branch Works

Out Details ................................. 209

Incentives for Complete Collections and Short Embargos . . . . . . . . . . 210

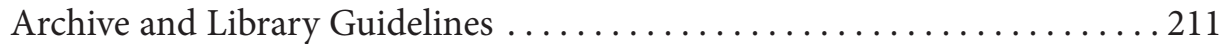

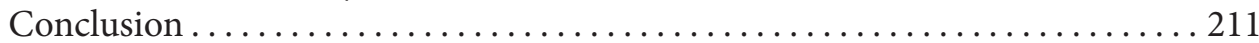

\section{Introduction}

I1 Following the unexpected death of Supreme Court Justice Antonin Scalia in early $2016,{ }^{2}$ it quickly came to the attention of legal scholars that Justice Scalia had not designated a repository for his papers before his passing. ${ }^{3}$ No law governs the preservation of federal judges' papers produced in the course of their work as employees of the United States. ${ }^{4}$ As a result, the fate of Scalia's papers was left in the hands of his family, who were free to do virtually anything with them. Papers of other Supreme Court Justices have been destroyed, lost, or heavily restricted. We now know that the Scalia family has chosen Harvard Law Library as the repository for the papers, but they have placed restrictions on them that will delay access to many of the papers for an indeterminate (but likely not short) period based on the lifespans of Scalia's colleagues. This delay will frustrate scholars and other researchers, and it will hamper further insight into the Court at a time when it appears to be undergoing an ideological shift further to the right. Justice Scalia spent twentynine years on the Court participating in many decisions that have shaped modern American society and jurisprudence. As Professor Gerard Magliocca of Indiana University noted, "Everyone will be dying to see [Scalia's papers]."

I2 For the American public as well as scholars of law, history, and government, the papers of all Supreme Court Justices are of vital importance. ${ }^{6}$ The insights gleaned from these papers contribute to biographies, histories, and legal critiques. Our understanding of the Constitution, our government, the Court, and its decisions is enriched by access to the thinking of the Justices. In turn, this knowledge informs our views on our laws and social order and helps shape the future of our legal, political, and even moral culture.

2. Jamie Gangel et al., Antonin Scalia, Supreme Court Justice, Dies at 79, CNN, Feb. 15, 2016, http://www.cnn.com/2016/02/13/politics/supreme-court-Justice-antonin-scalia-dies-at-79/index .html [https://perma.cc/V898-49WQ].

3. Tony Mauro, The Fate of Scalia's SCOTUS Papers Is Uncertain, NAT'L L.J., Feb. 22, 2016, at 19.

4. In this article, I use "papers" and "working papers" interchangeably to mean the documents created in the chambers of the Supreme Court Justices in the course of their government work. The public's interest is limited to the Justices' work as jurists and government employees, not their personal lives. Thus, I draw a distinction between private papers and working papers or, in some parlance, "public papers."

5. Mauro, supra note 3, at 19.

6. See infra III 27-48; see also Stephen Wermiel, Using the Papers of U.S. Supreme Court Justices: A Reflection, 57 N.Y.L. ScH. L. Rev. 499 (2012-2013). 
I3 Despite, or perhaps because of, high interest in these papers, many Justices who have donated their papers in the past seventy-five years or so have restricted access to the collections. These restrictions generally keep the papers closed until a certain amount of time has passed. This period may be a few years (rarely) or decades (usually), but the general trend is toward lengthy periods of time. ${ }^{7}$ This raises an important question: what perspective can we as librarians and archivists bring to this tug of war between access and privacy, two concepts that our profession holds in high esteem?

I4 This article explores the tension between access and privacy presented by the Justices' papers, and it proposes changes that will balance the public's interest in open government and insight into our legal system with respect for the confidentiality desired by the Court. Paragraphs five through twenty-six set forth the root of the problem-that the Supreme Court Justices continue to have personal ownership of their working papers, resulting in idiosyncratic retention and access decisions. Paragraphs twenty-seven through thirty-four explore the public's interest in access to the Justices' papers because of the Court's impact on our society, the nature of the Court and its operations, and its politicization. Paragraphs thirty-five through forty-eight investigate the effects of access on scholarship. Paragraphs forty-nine through seventyone weigh the Justices' privacy interests, and paragraphs seventy-two through eightynine offer proposals for change. The appendix lists the largest collection of papers for each Justice who served on the Court in the twentieth or twenty-first century along with access restrictions on those collections at the time they were established.

\section{The Problem: Justices Set the Rules on Access to Their Working Papers}

I5 The working papers of all federal judges, including Supreme Court Justices, are considered personal property rather than public property. No federal statute provides for the disposition of these papers. Neither does any policy of the Judicial Conference of the United States. Justices' staff and clerks can help organize the papers but can make no decisions about retention or disposition. The National Archives cannot accept the Justices' papers as part of the court records, and no court funds are available for preservation and disposition. The papers of the Justices and other federal judges are not provided even with temporary storage in federal records centers. ${ }^{8}$

I6 The lack of law or policy providing for retention of Justices' papers leaves plenty of room for the Justices to be idiosyncratic with their papers. Prior to the 1930s, the disposition of Supreme Court Justices' papers was, to put it simply, not a matter of particular concern to anyone. Some Justices destroyed their papers, though their motivations in doing so are unknown, but most left them in the hands of their heirs or gifted them to an archive with no restrictions.

I7 As evidenced in this article's appendix, this attitude started to change with Justice Louis Brandeis. Brandeis began turning over his papers to the University of Louisville in 1936, three years before he stepped down from the bench in 1939. According to internal letters at the university, at least some portion of these papers

7. See Appendix.

8. Fed. Judicial History Office, A Guide to the Preservation of Federal Judges' Papers 1 (2d ed. 2009). 
was to be kept closed, except by special permission, during the lifetime of Bernard Flexner, a lawyer and friend of Brandeis who facilitated the arrangements for the donation with the university. ${ }^{9}$ Flexner died in 1945 , only four years after the passing of Justice Brandeis.

I8 Justice Felix Frankfurter joined the Court the year Brandeis retired but was a longtime correspondent of Brandeis. Apparently, he was not pleased with Brandeis's gift of papers to the University of Louisville. According to legend, shortly after Brandeis's death in 1941, "Frankfurter went to Louisville, stormed into the library, asked for the file labelled 'Frankfurter', and took nearly everything out of it. 'These are my papers, and I'm taking them back', he told the librarian as he walked out the door, sheaf in hand." 10

19 When disposing of his own papers, Justice Frankfurter required that each document he gave to the Library of Congress be kept closed until sixteen years after the date of the document's creation. The papers that he donated to Harvard Law Library were closed except by special permission from a three-person panel of close friends and colleagues of Frankfurter's. ${ }^{11}$

I10 Some of Justice Frankfurter's peers seem to have shared his reservations about public access to their papers. Hugo Black, who served on the Court from 1937 to 1971, had many of his papers, particularly case files, destroyed. He was very private about his life and work and, according to one historian, his children referred to the burning of his papers as "Operation Frustrate the Historians."12 When the Sherman Minton papers, Stanley Reed papers, and Fred Vinson papers were donated in the 1970s, they were all given with restrictions that shielded the papers from public use for a time.

I11 This trend continued with Justice Potter Stewart gifting his papers to Yale University when he retired in 1981. He stipulated that the papers remain closed until the retirement of all those who served with him on the Court. This occurred in 2010 when Justice John Paul Stevens retired, twenty-nine years after the retirement of Justice Stewart. Justice Sandra Day O'Connor took the same approach as Justice Stewart when she gave her papers to the Library of Congress, tying access to the retirement of all those who served with her on the Court. ${ }^{13}$ It will likely be

9. Letter from J.N. Lott, Dean of the Univ. of Louisville Sch. of Law, to Dr. E.W. Jacobsen (Dec. 4,1945 ) (on file with author). It refers to Bernard Flexner, who was a friend of Brandeis and through whom donation of the papers was arranged. In the letter, Lott tells Jacobsen that "[d]uring Mr. Bernard Flexner's lifetime it was understood that the Brandeis papers were not to be examined by anyone without the consent of either Mr. Flexner or some member of the Brandeis family." Jacobsen may have been a member of the law faculty, in that the inside address for him is merely "Law School Building" and the printed heading on the letter indicates it is an "Interdepartmental Communication."

10. Jill Lepore, The Great Paper Caper, New Yorker, Dec. 1, 2014, at 32, 33.

11. According to information received from Harvard Law Library, there are no restrictions on the collection now.

12. Lepore, supra note 10 , at 32.

13. It is interesting to note that the Library of Congress's website includes a page discussing what information the Manuscript Division offers about women Justices, judges, and attorneys. The page opens with: “As suggested by the Sandra Day O’Connor and Ruth Bader Ginsburg collections described elsewhere, the papers of Supreme Court justices and appeals court judges contain a wealth of information on federal case law relating to women of all classes, races, and regions." See American Women: Manuscript Division, LIBR. OF Cong., https://memory.loc.gov/ammem/awhhtml/awmss5 /supreme.html [https://perma.cc/PA6W-YYN3]. The page also discusses what is found in the collections of many of the male Justices who preceded O'Connor and Ginsburg. 
many years yet until the opening of her papers to the public since she served with Justices Kennedy, Thomas, Ginsburg, Breyer, and Roberts.

I12 Chief Justice Rehnquist's Supreme Court papers, held at the Hoover Institute at Stanford University, are being opened on a rolling basis. According to the terms of his gift, the papers remain closed during the lifetimes of the Justices who served with him, but portions open as his former colleagues die. At this time, the papers from 1975 forward are closed since Justice Stevens is still very much alive. When his life ends, the next portion of Rehnquist's papers ${ }^{14}$ will open. This process will continue for an unknown number of years. Still-living Justices who served with Rehnquist include Justices Stevens, O’Connor, Kennedy, Souter, Thomas, Ginsburg, and Breyer.

I13 Justice Scalia’s judicial papers, now held at the Harvard Law Library, will open on a similar rolling basis as judges and Justices with whom he served die. This means the earliest any papers specific to Supreme Court cases will open is after the deaths of both Justices Stevens and O'Connor. Given the relative youth of Justice Thomas, it could be many years before any of Scalia's papers regarding cases after 1991, some of which are already more than 25 years old, are available. The youngest Justice with whom Scalia served is Justice Kagan. Born in 1960, she could easily live another thirty or more years.

I14 Justice David Souter took the most restrictive approach to date, short of destruction. Upon his retirement in 2009, Justice Souter gifted his papers to the New Hampshire Historical Society with the restriction that they not be made available to the public until fifty years after his death. At the time of this writing, Justice Souter is 78 years old; we will be well into the latter half of the twenty-first century before anyone has access to his papers.

I15 In contrast, Justice Harry Blackmun, who retired in 1994 at the age of 85, took a much less restrictive approach than his peers. The bequest of his papers to the Library of Congress kept the collection closed for only five years after his death, which occurred in 1999. When his papers were opened in 2004, three Justices with whom Blackmun had served were still at the Court: O'Connor, Rehnquist, and Stevens. No harm to his colleagues ensued, and the scholarship on Blackmun has benefited considerably from timely access to his collection. ${ }^{15}$

I16 By far the most controversial (at least at the time) access decision came about when Thurgood Marshall died in 1993, just two years after his retirement from the Supreme Court. He had donated his papers-a sizable collection of more than 170,000 items - to the Library of Congress. His deed of gift indicated that the papers were to remain closed during his lifetime. Upon his death, the collection was to be "made available to the public at the discretion of the Library."

14. This is likely to be the papers from 1975 to 1981, when Justice O'Connor joined the Court. If Stevens outlives O'Connor, the opened papers would include those through 1988 when Justice Kennedy joined the Court.

15. See infra III 39-48.

16. Instrument of Gift, Thurgood Marshall to Library of Congress Manuscript Division, Oct. 24, 1991, reprinted in Public Papers of Supreme Court Justices: Assuring Preservation and Access, Hearing Before the Subcommittee on Regulation and Government Information of the U.S. Senate Committee on Governmental Affairs, 103d Cong. 69 (1993) [hereinafter Senate Hearing]. 
I17 James Billington, then Librarian of Congress, opened the Marshall papers to the public shortly after the Justice's death. ${ }^{17}$ In May 1993, journalists from the Washington Post ran a three-day series of articles drawing on information contained in Marshall's papers. ${ }^{18}$ Other journalists quickly followed suit. ${ }^{19}$ It was not long before Marshall's former colleagues on the Court expressed their displeasure with the library's decision to release the papers.

I18 The controversy over Marshall's papers prompted a subcommittee of the Senate Committee on Governmental Affairs to convene a hearing on June 11, 1993, less than three weeks after the first article had appeared in the Washington Post. The hearings were conducted by Senators Joe Lieberman and Thad Cochran and included testimony from prominent figures at the Library of Congress, the press, the Supreme Court Review, and the Society of American Archivists. ${ }^{20}$ Participants generally agreed on a range of issues regarding judicial papers, many of which echoed the earlier Public Documents Commission Report issued in 1977 in the wake of Watergate: ${ }^{21}$

- Preservation of and access to Justices' papers are important public interests.

- Private ownership has allowed the Justices to be idiosyncratic in placing access restrictions on their collections of papers. These restrictions have, for the most part, become more severe in the past few decades, and these restrictions limit the public's understanding of the Court.

- Allowing for the passage of some period of time between a Justice's retirement and the opening of his or her papers is reasonable and even advisable, but that period should not be excessive. Justice Blackmun's papers serve as an instructive example here. They opened five years after his death, which was ten years after his retirement from the Court. Unlike the release of Justice Marshall's papers, the release of Justice Blackmun's papers caused no backlash from the Justices, nor did the restriction up until that point cause an outcry among scholars. Ten years seems to have been, at the very least, good enough for everyone.

- Once the papers are open, discrimination as to who can access them (e.g., giving access to "serious" scholars but not to journalists or those with only a passing curiosity) should not be allowed.

- It would be helpful to know more about the Justices' confidentiality concerns, but in light of the separation of powers doctrine and the

17. See Larry Weimer, An Embarrassment of Riches: Access and the Politics of Processing Congressional Collections, in An American Political ArChives ReAder 337 (Glenn Gray et al. eds., 2009).

18. Benjamin Weiser \& Joan Biskupic, Secrets of the High Court; Papers Afford a Rare Glimpse of Justices' Deliberations, WASH. Post, May 23, 1993, at A1; Benjamin Weiser \& Bob Woodward, Roe's Eleventh-Hour Reprieve; '89 Drafts Show Court Poised to Strike Abortion Ruling, Wash. Post, May 23, 1993, at A1; Joan Biskupic, How an Era Ended in Civil Rights Law, WAsH. Post, May 24, 1993, at A1; Fred Barbash \& Joan Biskupic, 1st Black Justice Unyielding in Rights Crusade, WAsH. Post, May 25, 1993, at A1.

19. Articles appeared that same week in USA Today, the New York Times, the Philadelphia Inquirer, the Los Angeles Times, the Kansas City Star, the Dallas Morning Post, and the Chicago Tribune, among others.

20. See generally Senate Hearing, supra note 16 , at 1.

21. See Nat'l Study Comm'n on Records \& Documents of Fed. Officials, Final Report of the National Study Commission on Records and Documents of Federal Officials 6 (1977) [hereinafter Commission FinAL RePORT]. 
traditions that surround the Court, it is not clear what, if anything, Congress ought to do about regulating preservation and access. ${ }^{22}$

I19 In the end, the hearing resulted in general agreement that Congress should not respond to calls to override James Billington and close the Marshall papers. Justice Marshall's Instrument of Gift entrusted discretion to the Librarian of Congress, and it would set a bad precedent if this entrustment were violated from the perspective of both archivists who implement donor agreements and current and future Justices who want their donative wishes followed. ${ }^{23}$ The hearing did not result in any action.

\$20 In the end, the controversy seemed largely unnecessary. All in all, the newspaper articles following the opening of Justice Marshall's papers showed that the Court was doing its job and functioning well given the independent nature of the Justices. Yes, there was debate and disagreement among the Justices, and sometimes Justices would change their minds, but that is how the Court is supposed to work.

I21 The downside is that Marshall's and Billington's decisions, which appeared to favor access, struck a blow to transparency in the end. As Chief Justice Rehnquist made clear at the Senate hearing, the Justices were not pleased, and those Justices who were serving at the time but have since retired have placed more severe restrictions on their archives than was typical prior to Marshall. It seems that the release of Justice Marshall's papers damaged the relationship of trust between the Justices and archivists, and that relationship has not yet recovered. Moving forward, if we want to encourage upper limits on restrictions, we need to ensure that lower limits exist as well and that records remain closed for a given time.

I22 We also need to recognize the risk that encouraging greater openness may cause Justices to simply destroy more of their papers rather than hazard unwanted scrutiny. This is a risk familiar to archivists. ${ }^{24}$ In her work on the balancing acts performed by archivists, Judith Schwarz notes that "[a]mid the complex motives of donors, there is often a desire to establish a favorable historical image of the recordcreating institution, family, or person. That desire can lead to a destruction of some materials before any are donated ..." ${ }^{25}$ In the context of the working papers of the Supreme Court Justices, perhaps the desire to create a favorable impression would actually countervail the urge to avoid scrutiny through destruction. Supreme Court Justices who destroyed their working papers years ago seem a bit peevish to us now, having denied posterity the records created when they held the highest judicial position in the nation. Meanwhile, the available collections have given rise to greater interest in the Court, greater understanding of the Justices, and greater respect for the difficult work they do. In short, the Justices leave far better impressions when their papers are available within a reasonable time after retirement (although not too soon) than when they are destroyed.

I23 The disparities between the Justices' choices and the extremes to which the ad hoc approach can go, as evidenced by the Marshall and Souter papers, lend credence to Professor Kathryn Watts's assertion that the private property model

22. See generally Senate Hearing, supra note 16.

23. Testimony of Anne R. Kenney, Senate Hearing, supra note 16, at 21-22.

24. See Judith Schwarz, The Archivist's Balancing Act: Helping Researchers While Protecting Individual Privacy, 79 J. Ам. Нisт. 179 (1992).

25. Id. 
applied to Justices' (and judges') papers "has proven ill-equipped to balance the many competing interests at stake, ranging from calls for governmental accountability and transparency on the one hand, to the judiciary's independence, confidentiality, collegiality, and integrity on the other." ${ }^{26}$ Instead it has resulted in unpredictable and idiosyncratic disposition of some of the most historically valuable papers produced by employees of the U.S. government. Remarkably, the idiosyncrasies do not even necessarily end when the papers are donated. With the stroke of a pen, a Justice can change his or her restrictions at any time. ${ }^{27}$

I24 An individual Justice's ability either to place severe restrictions or to ignore privacy concerns with restrictions that are too loose puts archivists in the position of flouting the general ethic of their profession-access balanced by privacy, not access subsumed by privacy. Furthermore, a donor's ability to change restrictions on a whim frustrates the ethic of access that is both determinable and equitable. The following excerpts from the Society of American Archivists' Core Values Statement are indicative of the Society's ethics as to access:

Access and Use: . . Although access may be limited in some instances, archivists seek to promote open access and use when possible. Access to records is essential in personal, academic, business, and government settings, and use of records should be both welcomed and actively promoted. Even individuals who do not directly use archival materials benefit indirectly from research, public programs, and other forms of archival use, including the symbolic value of knowing that such records exist and can be accessed when needed.

Accountability: By documenting institutional functions, activities, and decision-making, archivists provide an important means of ensuring accountability. In a republic such accountability and transparency constitute an essential hallmark of democracy. Public leaders must be held accountable both to the judgment of history and future generations as well as to citizens in the ongoing governance of society. Access to the records of public officials and agencies provides a means of holding them accountable both to public citizens and to the judgment of future generations. ${ }^{28}$

26. Kathryn A. Watts, Judges and Their Papers, 88 N.Y.U. L. Rev. 1665, 1665 (2013).

27. See, e.g., Ruth Panofsky \& Michael Moir, Halted by the Archive: The Impact of Excessive Archival Restrictions of Scholars, 37 J. Scholarly Pub. 19 (2005).

28. SAA Core Values Statement and Code of Ethics, Soc'y of Am. ARchivists, https://www2. archivists.org/statements/saa-core-values-statement-and-code-of-ethics\#core_values [https://perma. cc/7KXT-FP2P]. In its Code of Ethics for Archivists, the SAA also states that

[r] ecognizing that use is the fundamental reason for keeping archives, archivists actively promote open and equitable access to the records in their care within the context of their institutions' missions and their intended user groups. They minimize restrictions and maximize ease of access.... They work with donors and originating agencies to ensure that any restrictions are appropriate, welldocumented, and equitably enforced. When repositories require restrictions to protect confidential and proprietary information, such restrictions should be implemented in an impartial manner. In all questions of access, archivists seek practical solutions that balance competing principles and interests.

Id.

As to privacy, the Society recognizes its importance but places an emphasis on the privacy of those who had no say in the collection's disposition rather than the donor's privacy:

Archivists recognize that privacy is sanctioned by law. They establish procedures and policies to protect the interests of the donors, individuals, groups, and institutions whose public and private lives and activities are recorded in their holdings. As appropriate, archivists place access restrictions on collections to ensure that privacy and confidentiality are maintained, particularly for individuals and groups who have no voice or role in collections' creation, retention, or public use. 
I25 By and large, the public agrees with archivists about access to nonpersonal government information. In 1989, Elena S. Danielson, an archivist at the Hoover Institute, wrote of the increasing demands for both open and equitable access to archival materials, saying "public opinion is solidly on the side of the principle of open and equal access, at least in the United States." ${ }^{29}$ This has become only more accurate as we have grown accustomed to ready digital access to extensive amounts of information through the Internet.

I26 Danielson raises another problem resulting from the private property model and the Justices' idiosyncratic approach to access-that of equitable access. It is not at all uncommon for a Supreme Court Justice to handpick a biographer and give that person exclusive access to the papers that are closed to everyone else. Again, this forces librarians and archivists into a position that contradicts the very essence of their professions. As Sara Hodson explains in her work on curating the papers of authors and celebrities,

\begin{abstract}
curators and archivists should not acquire, except in extremely unusual circumstances, any papers that carry with them decrees of selective access in which the donor or other designated individual retains the right to decide, on a case-by-case basis, and according to his or her own criteria, who will be able to see the collection. Donors may wish to limit access in order to reserve an archive for the exclusive use of an authorized biographer, or of those who have demonstrated the proper reverence or respect for the papers' creator, or they may simply wish to wield power over the papers and over applicants for the donors' favor. Such selective availability ... contravenes the ethic of free and unfettered access that remains a cornerstone of the archival profession in a democratic society. ... ${ }^{30}$
\end{abstract}

\title{
The Public's Interest in Accessing Justices' Papers
}

\section{Nature and Power of the Court}

I27 The conflict between our professional ethic of access and the Justices' desire to remain secretive regarding the work of the Court prompts the question: how significant is the public's interest in access to the Justices' working papers? If we as librarians and archivists are seeking a balance between access and privacy, how much weight lies on the access side of the scale?

I28 The current mission statement of the National Archives and Records Administration states that "[p]ublic access to government records strengthens democracy by allowing Americans to claim their rights of citizenship, hold their government accountable, and understand their history so they can participate more effectively in their government." ${ }^{11}$ Similarly, Steven Aftergood notes that without disclosure of government information, "citizens are deprived of a meaningful role in the political process, and the exercise of authority is insulated from public oversight and control." ${ }^{2}$ Is it enough that we have access to the briefs, the transcripts

29. Elena S. Danielson, The Ethics of Access, 52 Aм. Archivist 52, 59 (1989).

30. Sara S. Hodson, In Secret Kept, In Silence Sealed: Privacy in the Papers of Authors and Celebrities, 67 Aм. Archivist 194, 198 (2004) (emphasis added); see also Timothy D. Pyatt, Southern Family Honor Tarnished? Issues of Privacy in the Walker Percy and Shelby Foote Papers, in PrIVACY AND Confidentiality Perspectives 141, 151 (Menzi L. Behrnd-Klodt \& Peter J. Wosh eds., 2005).

31. Vision and Mission, NAT'L ARchives \& ReCords Admin., https://www.archives.gov/about/info /mission.html [https://perma.cc/JZK4-BL8S].

32. Steven Aftergood, Reducing Government Secrecy: Finding What Works, 27 Yale L. \& Pol'y Rev. 399, 399 (2009). Although this article addresses the classification system for government information, Aftergood's point is valid in other contexts as well. 
and (more recently) recordings of the arguments before the Court, and the Court's opinions? To have a "meaningful role" and "public oversight and control" over the "exercise of authority," do we need access to the papers the Supreme Court Justices generate in their cogitations and negotiations?

I29 In the twentieth century, the Supreme Court ascended as the arbiter of our nation's most difficult questions, be they cultural, moral, or constitutional. ${ }^{33}$ Congress is characterized more by gridlock than anything else, and our presidents are engaged in wars, elections, and crisis management. As a result, "all sides now identify the Supreme Court as the key to American politics and policy-making." 34

\30 In its ascendancy, the Supreme Court has also become more politicized. The nomination process has become bitter, and the Justices have become less consensus-oriented. Five-to-four decisions and vituperative dissents, predictably along partisan lines, are frequent occurrences now. Empirical research shows that the Justices' decision making is both strategic and ideological. The work done by Lee Epstein and Jack Knight shows that the Justices bargain with one another for votes, ${ }^{35}$ adjust language to placate each other, ${ }^{36}$ and accommodate to ensure the continued legitimacy of the Court. ${ }^{37}$ Another study by Epstein, along with Landes and Posner, concludes that data from Supreme Court decisions show "strong evidence that ideology does influence the Justices' judicial votes, and thus the Court's outcomes, in a variety of cases, and that this ideological influence has been growing." ${ }^{38}$ In other words, despite protestations made to the contrary by nominees during their Senate hearings, Supreme Court Justices are more realist than

33. See William J. Quirk, Courts \& Congress (2008). Quirk argues that Congress is responsible for the Supreme Court's ascendancy. Members of Congress are particularly vulnerable to the ballot, so, says Quirk, they have passed off the most difficult governance decisions to the judicial and executive branches. This allows members of Congress to avoid tough decisions that might not sit well with voters. Thus the president has taken on the responsibility for all wars since World War II, and the Supreme Court has taken on the responsibility for the most challenging moral, cultural, and constitutional decisions. He labels this the Happy Convention, distinguishing the arrangement from the balance of power and decision making envisaged in the Constitution. Id. Jeffrey Rosen sees much the same result but asserts that the Supreme Court made the first move to expand its influence rather than responding to congressional off-loading of difficult decisions. Jeffrey Rosen, The Most DemoCRATIC Branch: How the Courts SERve America 10 (2006) ("In the twentieth century, however, the courts became increasingly aggressive about asserting their own exclusive authority to interpret the Constitution, embracing a defiant form of judicial supremacy. In response, the other branches of government became, not surprisingly, more passive.").

34. QUIRK, supra note 33, at 5.

35. Lee Epstein \& Jack Knight, Choices Justices Make 58-79 (1998).

36. Id. at $74-75$.

37. Id. at 46-49. Wahlbeck, Spriggs, and Maltzman reach a conclusion similar to that of Epstein and Knight. The willingness of Supreme Court Justices to accommodate their colleagues when writing an opinion

is influenced strongly by strategic concerns-including the size of the majority conference coalition, the ideological distance of the author from the majority coalition, the ideological heterogeneity of the conference majority coalition, and the positions taken by majority coalition members and by nonstrategic factors including the author's workload and the complexity of a case.

Paul J. Wahlbeck, James F. Spriggs \& Forrest Maltzman, Marshalling the Court: Bargaining and Accommodation on the United States Supreme Court, 42 AM. J. PoL. SCI. 294, 294 (1998).

38. Lee Epstein et al., The Behavior of Federal Judges: A Theoretical and Empirical Study of RATiONAL SCIENCE 103 (2013). 
legalist. ${ }^{39}$ These empirical studies are corroborated by extensive qualitative and anecdotal work..$^{40}$

I31 As Quirk puts it, this arrangement of power “'works all very neatly' except for the American people who know little about the nine individuals 'with enormous power over their lives."'41 The Supreme Court "will powerfully shape, and will often chart, the course of our lives as individuals, as communities, and as a nation." ${ }^{2}$ Its decisions affect our births, our educations, our livelihoods, our intimacies, our families, our illnesses, and our deaths. And, as Laurence Tribe points out, the Supreme Court does more than just play a role-it chooses the script, casts the parts, and directs the show. ${ }^{43}$

\$32 Although it wields remarkable influence on our society, the Supreme Court has shielded itself from the scrutiny to which the other branches of government are subject, keeping the American people at arm's length. Despite the fact that their published opinions include lengthy explanations, the Court's work is shrouded in a veil of secrecy. ${ }^{44}$ Those who work for the Court are under strict orders to keep their work confidential. ${ }^{45}$ The press has virtually no view behind the curtain. Cameras are not allowed in the courtroom, and for a reporter to get beyond press releases is "nearly impossible." ${ }^{46}$ In addition, many former Supreme Court clerks now hold

39. Legalism, or formalism, is the theory that judges make decisions solely by applying the law to facts. Realism, on the other hand, recognizes that judges, like everyone else, have individual senses of justice, ingrained ideologies, class, race, and gender identifications, religious upbringings, jobrelated concerns, and other "incentives and constraints." Id. at 3. Epstein, Landes, and Posner do not hold with an extreme view of legal realism in which every decision is political in nature but rather embrace a more nuanced realism that "attempt[s] to be realistic about judicial behavior." Id. See also generally Richard A. Posner, How Judges Think (2008); Jeffrey A. Segal \& Harold J. Spaeth, The Supreme Court and the Attitudinal Model (1993); Cass R. Sunstein et AL., Are Judges Political? An Empirical Analysis of the Federal Judiciary (2006); Lee Epstein \& Tonja Jacobi, The Strategic Analysis of Judicial Decisions, 6 AnN. Rev. L. \& Soc. Scr. 341 (2010); Joshua B. Fischman \& Tonja Jacobi, The Second Dimension of the Supreme Court, 57 WM. \& MARY L. Rev. 1671 (2016); Jeffrey R. Lax \& Charles M. Cameron, Bargaining and Opinion Assignment on the U.S. Supreme Court, 23 J.L. Econ. \& ORG. 276 (2007); William P. Marshall, Judicial Takings, Judicial Speech, and Doctrinal Acceptance of the Model of the Judge as Political Actor, 6 Duke J. Const. L. \& Pub. Pol'y 1 (2011).

40. See, e.g., Eric J. Segall, Supreme Myths: Why the Supreme Court Is Not a Court and Its Justices ARE Not Judges (2012). Segall unabashedly asserts that the Justices' decision making is not based in legalism but rather on value judgments. He goes so far as to characterize the Supreme Court as a "political veto council." He bases his conclusions on a close scrutiny of decisions that turns up inconsistencies and incoherencies that cannot be explained by anything other than short-term strategy and accommodation. See also EPsTEIN \& KNIGHT, supra note 35; EpsteIN ET AL., supra note 38; Linda Greenhouse, The U.S. Supreme Court: A Very Short Introduction (2012); Edward LaZarus, Closed Chambers: The Rise, Fall, and Future of the Modern Supreme Court (2005); Forrest Maltzman et al., Crafting the Law on the Supreme Court: The Collegial Game (2000); David M. O’Brien, Storm Center: The Supreme Court in American Politics (10th ed. 2014); Roosevelt, supra note 1; JefFrey Toobin, The Nine: Inside the Supreme Court (2008); Jefrrey Toobin, The Oath: The Obama White House and the Supreme Court (2013); Bob Woodward \& Scott Armstrong, The BRETHREN: INSIDE THE SUPREME COURT (1979).

41. QuirK, supra note 33, at 20.

42. Laurence H. Tribe, God Save This Honorable Court 139 (1984).

43. Id. ("In fact, even the term 'role' is misleading: it suggests that the Supreme Court is but one actor on the legal and political stage.... But if we have learned one thing from the history of our Court in the life of our country, it is that the Justices are not just so many actors on the stage. To them has fallen a large share of a far more basic function - that of playwright and director.").

44. See generally Covering the Supreme Court in the Digital Age (Richard Davis ed., 2014).

45. See, e.g., LaZARUs, supra note 40; Toobin, supra note 40.

46. QUiRK, supra note 33, at 20. 
influential positions in the legal profession, and most have little desire to lift the veil. $^{47}$

I33 The Court's inscrutability is enhanced by the lifetime tenure of the Justices. With no accountability to the electorate, the Justices' decisions are reviewable only by Congress, and then only when the decision interprets a federal statute and when Congress can muster the will to respond. Sometimes, Congress does review and respond to Supreme Court decisions, as it did when it passed the Americans with Disabilities Amendments Acts of 2008. ${ }^{48}$ In this act, Congress broadened application of the term "disability," which had been severely narrowed over time by the Supreme Court. ${ }^{49}$ Such instances of direct response to the Court are rare. ${ }^{50}$

I34 The distance between the Supreme Court and the public does enhance the dignity of the Court, as mystery always does, while familiarity breeds contempt. But the Justices' ability to shield their working papers for decades after they leave the Court takes the inscrutability well beyond preserving the dignity of the Court. Instead, it deprives people of knowledge about the governmental body that charts our society's cultural and moral decision making. In short, we have no guaranteed access to the materials that would enlighten us as to how the Court reaches its decisions. Hidden from us are the answers to such questions as: what institutional or strategic concerns influenced the decision and the language in which it was couched? What personal views were accommodated or sidestepped? What doubts were voiced? What voices silenced? Answers to these questions are important if we are to play a meaningful role in the political process. If nothing else, they can inform future nominations and approvals. Yet whether we ever have access to this information is a decision that rests in the hands of the very men and women who generate the information, and they are reluctant to share.

\section{Differential Treatment}

I35 It is also problematic that the Justices' papers are treated differently from executive branch papers. With the implementation of the Freedom of Information Act in 1967, federal agencies had to retain records and make them available to the public upon request. ${ }^{51}$ Then, following the Watergate scandal, Congress passed the Presidential Recordings and Materials Preservation Act of 1974, ${ }^{52}$ which required the White House to turn over all materials related to President Nixon's abuse of

47. Id.; see also David Margolick, Meet the Supremes, N.Y. Times, Sept. 23, 2007, at 71 ("[Former clerks] can be very full of themselves, priggish and protective, even proprietary, about the court. Just ask Edward Lazarus, who in 1998 published an account of his year clerking for Justice Blackmun; for his breach of omertà, his fellow clerks shunned him at Blackmun's funeral.”).

48. Pub. L. No. 110-325, 122 Stat. 3553 (2008).

49. Id. $\$ 2$ (specifically rejecting the Supreme Court's application of the definition of "disability").

50. This does not include congressional or state efforts to achieve Supreme Court approval for laws that skirt the edge of constitutional validity. New legislation responding to a Supreme Court decision that a gun control law or abortion law is too restrictive is relatively frequent, but in these situations there is no real "review" of the Supreme Court decision because constitutional determinations cannot be altered by any body except the Supreme Court itself.

51. Pub. L. No. 89-487, 80 Stat. 350 (1966). The Freedom of Information Act built on the groundwork established by the Federal Records Act of 1950, Pub. L. No. 81-754, 64 Stat. 578, 583. The Federal Records Act required federal agencies to maintain records and cooperate with the National Archives and Records Administration, which had been established in 1934, for long-term preservation and disposition.

52. Pub. L. No. 93-526, 88 Stat. 1695 (1974). 
power to the National Archives for retention, processing, and public access. In 1978, upon recommendation of the National Study Commission on Records and Documents of Federal Officials, ${ }^{53}$ Congress passed the Presidential Records Act (PRA), which expanded preservation requirements to all presidents and vice presidents beginning January 20, $1981 .{ }^{54}$ This act changed the ownership of presidential records ${ }^{55}$ from private to public.

I36 Although it passed the PRA, Congress ignored the commission's recommendation as to judicial papers. The commission had been tasked with studying the private ownership of presidential papers as well as those of all other elected and appointed federal officials, including judges. In its final report, issued in 1977, the commission recommended that judicial papers-those falling into a category the commission labeled "public papers"- be considered public rather than private property. According to the commission's report, these "public papers" would fall between "Federal records" 56 and "personal papers." The commission asserted that "public papers" should include those that were "produced by elected or appointed officials in their official capacity, were clearly clothed with a public interest, and were often the only source of the information upon which to form judgments necessary to the democratic process." 57 "Public papers" would include materials such as "confidential communications between an official and his staff; working papers reflecting the decision-making process; conference notes; and various other materials . ..."58 This is essentially what Congress did with records of the presidents and vice presidents in the PRA.

I37 Alongside this category of "public papers," the commission urged a definition of "personal papers" as those

of a purely private or non-official character and which were neither created nor received in connection with the conduct of constitutional or statutory duties. Personal papers might include diaries, family records, and correspondence not involving official duties. ${ }^{59}$

53. This study commission was simply known as the Public Documents Commission.

54. Pub. L. No. 95-591, 92 Stat. 2523 (1978).

55. "Presidential records" are defined as

documentary materials, or any reasonably segregable portion thereof, created or received by the President, the President's immediate staff, or a unit or individual of the Executive Office of the President whose function is to advise or assist the President, in the course of conducting activities which relate to or have an effect upon the carrying out of the constitutional, statutory, or other official or ceremonial duties of the President. Such term (A) includes any documentary materials relating to the political activities of the President or members of the President's staff, but only if such activities relate to or have a direct effect upon the carrying out of constitutional, statutory, or other official or ceremonial duties of the President ....

44 U.S.C. $\$ 2201(2)$ (Supp. I 2014).

56. "Federal records" was and still is defined statutorily to include all materials regardless of physical form or characteristics, made or received by [a Federal agency] under Federal law or in connection with the transaction of public business and preserved or appropriate for preservation by that agency ... as evidence of the organization, functions, policies, decisions, procedures, operations, or other activities of the Government or because of the informational value of data in them.

44 U.S.C. $\$ 3301$ (Supp. I 2014). The 1968 law used the phrasing "an agency of the United States Government" rather than "a Federal agency." This is notable since the term "Federal agency" has excluded the Supreme Court since 1984. See infra note 61. This appears to have been changed in 2014 by the Presidential and Federal Records Act Amendments of 2014, Pub. L. No. 113-187, 128 Stat. 2003. The 2014 amendments also clarified that digital or electronic records were included.

57. See Commission Final Report, supra note 21, at 6.

58. Id.

59. Id. 
In reaching these recommendations, the commission did an admirable job of hearing testimony from many different constituencies, including archivists and historians, and weighing the public's need for information in a democracy against negative effects on judges and Justices. Congress, however, did nothing with these recommendations. ${ }^{60}$ Then in 1984, Congress took the unexplained step of specifically excepting the Supreme Court from the definition of "Federal agency" in the Federal Records Act. ${ }^{61}$ As a result, the Supreme Court is not required to deposit its official materials in the National Archives. Nothing in the legislative history of this 1984 amendment specifically addresses this change, though the commission's final report from 1977 stated that the Archivist of the United States had always acted on the assumption that the Supreme Court did not fall within the scope of the statutory definition of "federal agency." ${ }^{2}$ The exception added in 1984 originated in the Senate and was agreed to in conference. As it happens, the Supreme Court has authorized the deposit of many of its records (which do not include the Justices' papers) with the National Archives, which now holds records through $1997 .{ }^{63}$ Those since 1997 remain at the Supreme Court Library. ${ }^{64}$

I38 It is worth noting that when Congress passed the PRA, it also ignored the commission's recommendations as to its own members' papers. Arguably, then, the

60. All the bills introduced in 1974, 1975, 1977, and 1978 that culminated in the Presidential Records Act dealt only with the records of the executive branch, particularly the president and vice president. Indeed, it was asserted by Philip W. Buchen, former counsel to the president, in a hearing in front of a subcommittee of the House Committee on Government Operations, that presidential papers would be of more interest and usefulness than the papers of legislators or judges and Justices and would offer, to put it in colloquial terms, the most bang for the buck. He went on to say, however, that Congress should also do to itself what it wanted to do to the executive. Hearings on H.R. 10998 and Related Bills to Amend the Freedom of Information Act to Insure Public Access to the Official Papers of the President, and for Other Purposes, Before a Subcomm. of the Comm. on Government Operations House of Representatives, 95th Cong. 29, 32 (1978) (statement of Philip W. Buchen, former Counsel to the President).

61. Pub. L. No. 98-497, 98 Stat. 2280 (1984). Prior to this law, the definition of "Federal agency" included "any executive agency or any establishment in the legislative or judicial branch of the Government (except the Senate, House of Representatives, and the Architect of the Capitol and any activities under his direction)." In 1984, Congress changed this definition to "the term "Federal agency' means any executive agency or any establishment in the legislative or judicial branch of the Government (except the Supreme Court, the Senate, the House of Representatives, and the Architect of the Capitol and any activities under the direction of the Architect of the Capitol)."

62. Commission Final Report, supra note 21, at 25.

63. Guide to Federal Records: Records of the Supreme Court of the United States, NAT'L ArCHIVES \& RECORDS Admin., https://www.archives.gov/research/guide-fed-records/groups/267.html [https:// perma.cc/4N2V-R93Y].

64. The Supreme Court discussed the common law right of access to judicial records in Nixon $v$. Warner Communications, 435 U.S. 589 (1978). The Supreme Court wrestled with the issue of privacy versus public access regarding tape recordings that had been submitted as evidence-and played in court-during trials following Watergate. The Court recognized a common law right of access to judicial records and noted that, although infrequently litigated, past court decisions had found that a desire to "keep a watchful eye on the workings of public agencies" and "publish information concerning the operation of government" were adequate interests to support exercise of the right. $I d$. at 598. The Court declined, however, to decide Nixon's dispute with Warner Communications on this common law basis. The Presidential Recordings and Materials Act, which provided for the eventual release of the tapes and similar materials created by President Nixon, had recently been passed by Congress. This, the Court said, would take care of the dispute in due time. Plus, by deferring to the process established by the legislature, the Court avoided frustrating "the achievement of any legislative goals of orderly processing and protection of the rights of all affected persons." Id. at 606. 
judicial and legislative branches are treated alike. However, as Watts points out in her work on this subject, the activities of the legislative branch are subject to far more scrutiny than the judicial branch. Television cameras roll on the House and Senate floors twenty-four hours a day. Debate is recorded for posterity. Committees hold public hearings, publish transcripts, and issue reports. ${ }^{65}$ And, in the end, members of Congress can be voted out of office. The Supreme Court is subject to none of this scrutiny or accountability. All we can do is scour the Justices' opinions; the rest is speculation.

\section{Effect of Access to Justices' Papers on Scholarship and Knowledge}

I39 What happens when we do have access to the Justices' papers? Journalist and legal scholar Stephen Wermiel asserts that the use of Justices' papers to craft insights into the Court's decisions and inner workings began in the 1950s. Alpheus T. Mason published Justice Harlan Fiske Stone: Pillar of the Law in $1956 .{ }^{66}$ Alexander M. Bickel's The Unpublished Opinions of Mr. Justice Brennan: The Supreme Court at Work quickly followed in $1957 .{ }^{67}$ According to Wermiel, the paradigm shift was complete by the end of the 1970s with the publication of Richard Kluger's Simple Justice: The History of Brown v. Board of Education and Black America's Struggle for Equality, ${ }^{68}$ which made use of the notes of Justices Harold Burton, Felix Frankfurter, and others; and Bob Woodward and Scott Armstrong's The Brethren: Inside the Supreme Court, ${ }^{69}$ which also relied heavily on available papers. ${ }^{70}$ These popular books were read by more people than just legal scholars and had a considerable effect on the nation's knowledge of and interest in the Supreme Court.

I40 Further investigation provides other evidence that Supreme Court and constitutional law scholarship is both shaped and enhanced by the availability of Justices' papers. This research has shed light on the politico-strategic nature of the Justices' decision making and the (sometimes less influential than expected) role of ideology. Consider the following examples.

65. Unfortunately, the openness of congressional activities is not ensured. In the summer of 2017, a select group of Republicans held closed-door meetings to draft a healthcare law that was intended to "repeal and replace" the Affordable Care Act. Neither their colleagues nor the public was pleased, and in the end, the legislation was defeated. It is also a frustration to researchers that documents such as Congressional Research Service reports and even committee reports do not have to be made available to the public. See, e.g., Laura Litvan, GOP Health Bill Kept Secret from Senators Assigned to Write It, Bloomberg Politics, June 20, 2017, 4:04 PM EDT, https://www.bloomberg.com/news /articles/2017-06-20/senate-republicans-haven-t-seen-their-secret-health-bill-either.

66. Alpheus T. Mason, Justice Harlan Fiske Stone: Pillar of the Law (1956).

67. Alexander M. Bickel, The Unpublished Opinions of Mr. Justice Brennan: The Supreme COURT AT WORK (1957).

68. Richard Kluger, Simple Justice: The History of Brown v. Board of Education and Black America's Struggle for Equality (1975).

69. WoOdWARd \& Armstrong, supra note 40. The Anthony Lewis papers at the Library of Congress contain materials that raise questions about some of the assertions in The Brethren. For more on the Anthony Lewis papers, see Anthony Lewis Papers, 1941-1975, Libr. of Cong., https://www.loc .gov/item/mm81075856/ [https://perma.cc/X4R2-C3RU]. This is only further evidence of the importance of access to collections, so that the truth about our Supreme Court can be known.

70. Wermiel, supra note 6. Wermiel asserts that these publications prompted the Justices to respond with increasingly protective restrictions on their papers. $I d$. at 502-04. According to Justice Hugo Black's son, this was when his father decided that he wanted his own papers to be destroyed. Id. at 501 (citing Hugo Black, Jr., My Father: A Remembrance 250-51 (1975)). Yet Brandeis's restrictions on his papers occurred in the 1930s, and Frankfurter's purported trip to Louisville to reclaim his papers from Brandeis's archive occurred in 1941. 
I41 In The Choices Justices Make, Lee Epstein and Jack Knight explicitly state their reliance on the Justices' papers:

$[\mathrm{O}]$ ur focus on the Burger Court era is by no means accidental. We needed to collect most of the data from the Justices' papers rather than from published sources. For the Burger Court years, we could access (1) the case files of Marshall and Brennan, who served during the entire period; (2) Justice Powell's records, including case files, dockets books, and conference notes, dating from January 1972; and (3) Brennan's conference notes and docket books - records that scholars have deemed highly reliable and comprehensive. ... These data constitute our primary samples. ${ }^{71}$

I42 Forrest Maltzman, James Spriggs, and Paul Wahlbeck similarly depend on the Justices' papers in exploring the strategic nature of the Justices' decision making. ${ }^{72}$ For example, in Pennsylvania v. Muniz, Justice Brennan wrote a majority opinion regarding Miranda warnings that broke rather dramatically from his usual Fifth Amendment jurisprudence. Maltzman and his coauthors ask,

Why did Brennan author an opinion that restricted individual liberties? And why did Marshall refuse to join his ideological ally, while Brennan's usual adversaries chose to join his opinion? The answers become clear when we delve into the personal papers of the justices. In a letter to Marshall dated June 7, 1990, Justice Brennan informed Marshall that although "everyone except you and me would recognize the existence of an exception to Miranda for 'routine booking questions,' ... I made the strategic judgment to concede the existence of an exception but to use my control over the opinion to define the exception as narrowly as possible."73

I43 In Closed Chambers: The Rise, Fall, and Future of the Modern Supreme Court, former Blackmun clerk Edward Lazarus acknowledges that the papers of Justices Blackmun, Marshall, Brennan, Douglas, and Jackson contributed to his research. ${ }^{74}$ In the preface to the tenth edition of The Supreme Court in American Politics, David O'Brien notes that this edition “includes new material from recently released papers of Chief Justice Rehnquist and Justices Potter Stewart and Byron White." ${ }^{25}$ Earlier editions also used the papers of Justices Blackmun, Marshall, and Powell as those collections were already open to public access ${ }^{76}$ - all in addition to the papers of sixty-three Justices consulted for the first edition. ${ }^{77}$

I44 In 2001, Del Dickson published The Supreme Court in Conference, a oneof-a-kind compilation of conference notes drawn from collections available at the time. ${ }^{78}$ Dickson mentions that permission was needed to use the conference notes of Justices Douglas, Brennan, Jackson, and Black, which he was granted. He also gives "special credit" to Justices Burton, Frankfurter, and Warren for placing "all or part of their collection in the public domain...." More than 120 law review articles

71. Epstein \& Knight, supra note 35, at xv.

72. MALTZMAN ET AL., supra note 40 , at 3.

73. Id. (citation omitted); see also Wahlbeck et al., supra note 37, at 314 (noting the authors' use of memos found in the papers of Justices Brennan and Marshall; these memos were written by Justices Brennan, Marshall, Stewart, and White).

74. LAzARUs, supra note 40 , at viii.

75. O'BriEN, supra note 40 , at xiv.

76. $I d$.

77. Id. at Xvii.

78. The Supreme Court in Conference (1940-1985): The Private Discussions Behind Nearly 300 Supreme Court Decisions (Del Dickson ed., 2001). 
have used and cited Dickson's work since its publication. ${ }^{79}$ As it is unlikely that 120 authors would have received the permissions granted to Dickson, our scholarship would have been diminished were it not for Dickson's work. This is a striking example of the richness added to legal scholarship when the Justices' papers are made available and the unmeasurable loss to scholarship that results from restrictions.

I45 Not surprisingly, biographers also rely on the Justices' papers. Author Howard Ball acknowledged the help of librarians in accessing manuscript collections for his biography of Hugo Black, and the notes include citations to ten collections of the Justice's papers. ${ }^{80}$ Gerald T. Dunne's book on Justice Black likewise cites to the papers of both Justice Black and Justice Frankfurter. ${ }^{81}$ Stephen Wermiel had access to Justice Brennan's papers while writing Justice Brennan: Liberal Champion. ${ }^{82}$ Wermiel and coauthor Seth Stern also cite to the papers of Hugo Black, Harry Blackmun, Tom Clark, William Douglas, Abe Fortas, Felix Frankfurter, Arthur Goldberg, John Marshall Harlan, Thurgood Marshall, Lewis Powell, and Earl Warren. ${ }^{83}$

I46 Other biographers have spoken about the lack of access to some Justices' papers. In his recent work on Chief Justice Earl Warren, Paul Moke questions the reliability of some of what has been written about Warren, as published portrayals of his life may have been scripted for political reasons given his earlier role as a political figure. Moke notes that the problem is compounded by the fact that Warren burned all his correspondence with his colleagues on the Court. ${ }^{84}$ In a similar vein, Michael J. Graetz and Linda Greenhouse express particular gratitude to the Justices who have made their papers available, adding to the depth of their 2016 book, The Burger Court and the Rise of the Judicial Right. Graetz and Greenhouse note, without further comment, that Burger's own papers remain unavailable until $2026 .{ }^{85}$

I47 Archivists' ethical stance against unequal access to papers was discussed above. ${ }^{86}$ The Justices' habit of creating unequal access by anointing a biographer and giving him or her exclusive access to the working papers can have a considerable effect on scholarship. One effect is delay. For example, Wermiel was granted exclusive access to Justice Brennan's papers but took twenty-five years to publish his work. ${ }^{87}$ Meanwhile, the public waited.

I48 In addition to delay, errors can go uncorrected or the record can be left incomplete. Consider the example of Bennett Boskey, who clerked for Chief Justice Harlan Fiske Stone and Justice Stanley Reed in the early 1940s. When he left his last clerkship, Boskey took nine volumes of memos with him-memos he and his coclerks had written. Because papers produced in the Justices' chambers are considered personal rather than government property, Boskey was free to do so, and the

79. Results of a search in Westlaw's database of law reviews and journals for the following: adv: "del dickson" w/15 "supreme court in conference."

80. Howard Ball, Hugo L. Black: Cold Steel Warrior 253-88 (1996).

81. Gerald T. Dunne, Hugo Black and the Judicial Revolution 470-72 (1977).

82. Seth Stern \& Stephen Wermiel, Justice Brennan: Liberal Champion 550 (2010).

83. Id. at 557.

84. Paul Moke, Earl Warren and the Struggle for Justice 14-15 (2015).

85. Michael J. Graetz \& Linda Greenhouse, The Burger Court and the Rise of the Judicial Right 10 (2016).

86. See supra III $5-26$.

87. Jeffrey Toobin, A Not So Brief Recess, New Yorker, Jan. 5, 2004, at 28. 
Justices gladly approved of his interest. After Stone's death, a biographer was given exclusive access to the Chief Justice's papers. Boskey became disenchanted with the biographer and kept his memos to himself. The memos, which are of scholarly interest, did not come to light until $2015{ }^{88}$

\section{Privacy Interests}

\section{The Justices' Privacy Interests}

I49 In light of all this weight on the side of access, what weighs on the side of privacy? In a 1960 article, William Prosser identified the four privacy interests protected by common law. These were later incorporated into the Restatement (Second) of Torts. They are the interests in being free from

- intrusion upon seclusion or intrusion into private affairs;

- public disclosure of embarrassing private facts;

- publicity that places the person in a false light; and

- appropriation of one's name or likeness for another's advantage. ${ }^{89}$

I50 The first three categories require consideration. As for Prosser's fourth category, a Justice's name or likeness could be appropriated by someone for that person's advantage, but this harm would not arise from access to the Justice's papers.

I51 The interest in protection from public disclosure of embarrassing facts necessitates that the facts be private. "Private" generally implies that the facts are related to one's personal life-health, sexual activities, and family life. The papers of the Justices are work produced in the course of government employment, not material related to their private lives. "Private facts" would not be present. The private facts must also be offensive to a reasonable person of ordinary sensibilities, a circumstance unlikely to occur in the Justices' working papers, the Rehnquist memo discussed below ${ }^{90}$ notwithstanding.

I52 The offensiveness to a reasonable person of ordinary sensibilities is also required when the interest is protection from publicity that places a person in a false light. In addition, with this latter interest, the publicity must involve falseness or invention, ${ }^{91}$ which would actually be more difficult for someone with nefarious intent to achieve if there were more access to the Justices' papers rather than less, since there would be more opportunity for others to counter the "invention."

I53 It is Prosser's first category, the intrusion into private affairs, that may strike the closest at what the Justices feel they might suffer: unwanted scrutiny into communications and contemplations that were intended to be safe for open dialogue and experimental thinking. This concern is a sympathetic one. No one appreciates it when conversations that occur behind closed doors are made public. The problem with fitting this concern into Prosser's category is, once again, that the private

88. See Ross E. Davies, Some Clerical Contributions to Ex parte Quirin, 19 GreEN BAg 2d 283 (2016). Davies was given the memos by Boskey.

89. William L. Prosser, Privacy, 48 Cal. L. Rev. 383, 389 (1960); Restatement (Second) of Torts ch. 28A (Ам. LAW Inst. 1977).

90. See infra III 66-70.

91. Prosser, supra note 89 , at 400 . 
affairs contemplated by tort law relate to personal lives, not work done in governmental service.

I54 This uneasiness is exacerbated by the doctrine that "there is no liability when [public figures] are given additional publicity, as to matters reasonably within the scope of the public interest which they have aroused." ${ }^{2}$ Prosser states that a public figure "has been defined as a person who, by his accomplishments, fame, mode of living, or by adopting a profession or calling which gives the public a legitimate interest in his doings, his affairs, and his character, has become a 'public personage."'93 This certainly sounds like today's Supreme Court Justices.

I55 So far, the customary privacy interests and possible violations do not easily fit the Justices' papers. Prosser's four privacy interests reflect only the common law of torts and are limited by the time in which he wrote. Since Prosser's time, constitutional and statutory privacy protections have expanded significantly. In addition, our ability to collect, manipulate, aggregate, store, and share digital information has changed the privacy landscape dramatically. Many scholars have expanded the discussion of the nature of privacy, the legal right to privacy, and harms resulting from invasions of privacy beyond Prosser's four interests. This article is not the forum for a thorough look at this discussion, but two recent contributions help frame the privacy interests the Justices might have in their working papers.

I56 In A Taxonomy of Privacy, ${ }^{94}$ Daniel Solove develops a schema of sixteen privacy harms arising from four activities. These four activities are information collecting, information processing, information dissemination, and invasion. ${ }^{95}$ Of these, the activity of information dissemination gives rise to those harms most relevant to the Justices' papers. These harms include breach of confidentiality, disclosure, and increased accessibility, all of which are related to Prosser's tort of intrusion into private affairs. ${ }^{96}$ Breach of confidentiality and disclosure are two sides of the same coin-true information being revealed. Breach of confidentiality speaks to the harm done to a relationship of trust while disclosure regards the harm done to reputation. No doubt the Justices are worried about their reputations through disclosure, but it may well be harm to the relationships with the other Justices and with their clerks that is the greater concern. Given the responsibility of their positions, the difficulty of the work they do, and the fact that they often work together for decades, trust must be a key element in the functioning of the Supreme Court. This is reflected in the decisions made by several Justices to delay the opening of their papers until after the retirements or deaths of their colleagues on the bench.

I57 Solove's harm of increased accessibility occurs when information that was available but obscured by difficulty of access is suddenly much easier to find due to digitization. ${ }^{97}$ This issue has been a significant concern in the digitization of court filings, which used to require a weary trip to the courthouse for access. ${ }^{98}$ This article

92. Id. at 412 (citation omitted).

93. Id. at 410 .

94. Daniel J. Solove, A Taxonomy of Privacy, 154 U. PA. L. Rev. 477 (2006).

95. Id. at 489.

96. Id. at $526-29$.

97. Id. at $539-40$.

98. See David S. Ardia \& Anne Klinefelter, Privacy and Court Records: An Empirical Study, 30 BERKELEY TeCH. L.J. 1807 (2015). For a case study on University of North Carolina Law Library's experience with digitizing court records, see Nicole M. Downing, The UNC Law Library's Redaction of its Digitized Collection of North Carolina Supreme Court Briefs: A Case Study (May 2014) (unpublished 
does not tackle questions of digitizing Justices' papers; it advocates for earlier (or later in rare cases), more predictable, and more equitable access. The changes in practice being advocated here would not cause the profound leap in accessibility that digitizing does. If these changes were adopted, it is largely the timing that would change, not the ease of use.

I58 Aside from identifying these three possible harms, Solove's taxonomy sheds little light on questions surrounding the Justices' privacy interests. Solove focuses more on the collection of information about individuals through surveillance, online tracking, and electronic aggregation, along with the use and misuse of that data. Koops and colleagues take a different approach in A Typology of Privacy, ${ }^{99}$ delineating types of privacy rather than harms and searching for "ideal" renditions of these types using legal sources from multiple countries. The authors create an array of eight types of privacy that range along two axes: one axis that indicates the zone in which the information occurs, moving from a personal zone to the public zone, and one axis that represents the shift from a positive concept of privacy (freedom to ...) to a negative concept of privacy (freedom from ...). ${ }^{100}$ An additional layer that touches all eight underlying types of privacy is "informational privacy." From this typology, intellectual privacy and decisional privacy are the two types that best fit what we can discern of the Justices' interests. ${ }^{101}$

I59 The intellectual privacy type, derived in part from the protection of documents afforded by the Fourth Amendment, protects against scrutiny of one's thoughts. Other constitutional values are also reflected in intellectual privacy. For example, intellectual privacy facilitates both freedom of expression and freedom of association. Obviously, the papers of the Justices contain expressions of their own thinking and communications with others about ideas. That is what makes them valuable to researchers. The problem is that the concern in Koops' intellectual privacy is keeping the government out of peoples' private lives. With the Justices' papers, it is the people who want to see into the veiled life of the government.

I60 This same issue arises with Koops' decisional privacy. Although the term "decisional" sounds appropriate to materials created by the Justices, the decisions they are making are not the kinds of personal decisions protected by this decisional privacy. Decisional privacy protects decisions such as those surrounding "sex, sexuality, and child rearing." 102 Medical, religious, and to a certain degree educational decisions are also largely protected. All of these are protected because they are personal or family decisions, and it is inappropriate for the government to interfere. It does not follow that the decision-making processes of government employees should be protected from the public eye, especially when the public has no power to interfere with those decisions.

M.S.L.S. thesis, University of North Carolina), https://works.bepress.com/aallcallforpapers/84/down load/ [https://perma.cc/6JX7-X6AW].

99. Bert-Jaap Koops et al., A Typology of Privacy, 38 U. PA. J. InT'L L. 483 (2017).

100. Id. at 566. The four positive types of privacy are, moving from a private zone to a public zone, intellectual privacy, decisional privacy, associational privacy, and behavioral privacy. The four negative privacies, again moving from private to public, are bodily privacy, spatial privacy, communicational privacy, and proprietary privacy.

101. Koops et al. also discuss a communicational privacy, which sounds promising but focuses more on government interference with telecommunications, documents sent via mail, and personal conversations. $I d$. at 523-26.

102. Id. at 533 . 
I61 It is also possible to link the Justices' papers with Koops' proprietary privacy type, which is “a person's interest in using property as a means to shield activity, facts, things, or information from the view of others." 103 The Justices do employ the private ownership of their papers to shield information, but to conclude that because they can do so means they have a protection-worthy interest in doing so would require circular reasoning.

I62 The Justices have given little explanation of what they see as their privacy interest. When writing to the Librarian of Congress in the wake of the Marshall papers' release, Chief Justice William Rehnquist stated that a majority of the Justices were "surprised and disappointed" in the unexpectedly early release "[g]iven the Court's long tradition of confidentiality in its deliberations." 104 This confidentiality and the trust relationship it supports, which mirror the breach of confidentiality harm seen in the discussion of Solove's taxonomy above, seem to best articulate what the Justices want to protect.

I63 The desire to protect the confidentiality of conference and chamber is intuitively understandable, at least to a degree. The Justices need to be able to consider all angles of a decision, weigh different outcomes, and experiment with logic and language-and they want to be free from fear of embarrassment or misunderstanding while doing so. ${ }^{105}$ Arguably, the tradition of confidentiality results in more thoughtful and balanced decisions, to the benefit of our society. Without protection, the argument goes, communications and contemplations within the Supreme Court would be chilled.

I64 Thus far, however, there has been no real indication that access to a Justice's papers results in a harmful chilling effect. The Justices expressed dismay when the Marshall papers were opened just two years after his retirement, yet the papers revealed nothing shocking or scandalous. Instead, they indicated that the Supreme Court Justices share ideas, disagree, adjust their thinking, and wrangle over word choice-activities one would expect of a deliberative judicial body and matters of interest to serious scholars rather than scandalmongers. Then, when Justice Blackmun's papers became available in 2004, their contents gave no indication of a discernible change in the Justices' behavior after Marshall's papers were made public in 1993. Furthermore, in the Senate hearing that followed the opening of the Marshall papers, Dennis Hutchinson in particular pointed out that earlier publications such as The Brethren and Alpheus T. Mason's biography of Justice Stone, which liberally quoted still-sitting Justices, did not seem to chill the court's internal functions. ${ }^{106}$ Without evidence of a chilling effect, we are left with little beyond the

103. Koops et al., supra note 99, at 567.

104. Letter from Chief Justice William H. Rehnquist to Sen. Joseph I. Lieberman, June 7, 1993, reprinted in Senate Hearing, supra note 16, at 71.

105. An issue raised occasionally in discussions about the Justices' papers is the applicability of the attorney work product privilege. The privilege for attorney work product applies to documents prepared in anticipation of litigation, protecting an attorney's notes, drafts, plans, and other documents that reflect the attorney's thought processes and ideas regarding the litigation. The privilege means that these documents either do not have to be turned over to opposing counsel or can be redacted before being shared in discovery. It does not apply to the papers of the Justices or any other judge as they are not preparing to represent a client in a litigation and concerns about fairness in discovery are irrelevant.

106. Testimony of Dennis J. Hutchinson, Editor, Supreme Court Review, Senate Hearing, supra note 16 , at 19. 
Justices' insistence that their work must be kept confidential and no explanation as to why.

I65 In a 1994 article, following the tempest surrounding the Marshall papers, Harold M. Hyman, law professor and president of the American Society for Legal History, wrote, "The Court's secrecy tradition endures in part perhaps because, historically, many Justices dislike revelations that what they do is part of governing. Marshall's notes suggest that the Court's conference committee sessions reflect many of the tensions exhibited also in the White House and Congress." 107 Yet, as Hyman also points out, "[i]t has been a long time since scholarly Court-watchers believed, or justices asserted, that the Court's decisions resulted only from dispassionate philosophical consistencies or clashing convictions about the intentions of the Constitution's framers." 108 Scholarship in the years since Hyman wrote has made it only more apparent that the Supreme Court is a politicized governing body. ${ }^{109}$

\section{Supreme Court Clerks' Privacy Interests}

\66 The Justices’ clerks have their own privacy concerns. The Justices’ working papers include materials written by their clerks. These men and women are not public figures to the extent the Justices are, though quite a few go on to be public figures later in their careers. Furthermore, the clerks tend to be young and likely to still be professionally active, perhaps at the height of their careers, when the Justices' papers are finally made available. Do the judicial clerks have a privacy interest in the memos and other materials they produce in the Justices' chambers? Will the clerks feel less free to express themselves if they know their work will be publically scrutinized later in their careers?

I67 A memo regarding Brown v. Board of Education written by then-clerk William Rehnquist to Justice Robert Jackson is one example. In this memo, which was in Justice Jackson's collection of papers, Rehnquist wrote that he believed the Plessy decision upholding "separate but equal" was correct and should be reaffirmed. This memo and the views expressed therein were raised at Rehnquist's confirmation hearings when he was nominated to the Supreme Court by Richard Nixon, though obviously it did not stop the confirmation. ${ }^{110}$ Elena Kagan also had to field questions about materials written while she was a clerk for Justice Thurgood Marshall. ${ }^{111}$ Although their Supreme Court memos were still unavailable, John Roberts and Samuel Alito were questioned about memos written in other federal government positions. ${ }^{112}$

107. Harold M. Hyman, The Marshall Papers: Community of Interest or Conflict on Capitol Hill?, Persp. Hist., May 1994, at 7, 8.

108. Id. at 7 .

109. See supra $\mathbb{I I I} 27-34$.

110. See Brad Snyder \& John Q. Barrett, Rehnquist's Missing Letter: A Former Law Clerk's 1955 Thoughts on Justice Jackson and Brown, 53 B.C. L. Rev. 631, 632-34 (2012).

111. Robert Barnes, Kagan Nomination Focuses Attention on Court Clerkships; Relevance of Earlier Work Debated, WASH. Post, June 14, 2010, at A15.

112. Amy Goldstein, Democrats Dissect Memos from 1980s; Nominee Attempts to Create Distance, WASH. Post, Sept. 15, 2005, at A13; Amy Goldstein \& Charles Babington, Alito Stresses "Rule of Law" in Opening Statement; Senate Questioning of Supreme Court Pick Begins Today, WasH. Post, Jan. 10, 2006, at A1. 
I68 It can be argued that these sorts of revelations and questions regarding the work of Supreme Court clerks are reason to limit access to Justices' papers. Likely, then-nominee Rehnquist might have wished that Justice Jackson's papers had been unavailable or that his younger self had been more circumspect, yet there is a certain fairness to the idea that those who want to hold the most influential judgeships in the nation should be accountable for the words they used as clerks-words written in a professional setting by government employees who are already elite and powerful members of society with significant influence on our legal system and who are on a well-established trajectory to become even more elite and powerful. It seems strange, then, that we might harbor deep concern for the privacy of the Supreme Court clerks when it comes to the work they produce in the course of their employment in the chambers simply because their work now resides among the Justices' papers. Furthermore, it is hard to maintain that access to Justice Jackson's papers was destructive or would have a chilling effect on other clerks when Rehnquist not only won Senate confirmation in 1972 but also was later elevated to Chief Justice.

\$69 Also, any chilling effect from fear of future scrutiny would have to be small because future access is already a very strong likelihood; the fear, if it is a concern, should already be present. When a clerk accepts an offer from a Supreme Court Justice, he knows that he is agreeing to do governmental work of profound public interest, much as a Justice does. He also knows that his work will be among the Justice's papers and that the Justice can do anything she wants with those papers, including releasing them immediately upon retirement. If the clerk is concerned about his words coming back to haunt him in the future, the current regime should be plenty chilling. The clerks already have very little privacy within their control when it comes to their work for the Court.

I70 It is also arguable that some chilling effect might not be all bad. We want those advising our top jurists to speak freely but, at the same time, the American people are not well served if those advisers extol extreme views. To the extent that chilling occurs, it may serve to prevent extremism. Supreme Court clerks are intelligent and talented enough to present the full panoply of views and legal options without taking such extreme views that would later prove embarrassing. This circles back to the Rehnquist memo and the notion that if extreme views are being expressed by Supreme Court clerks, it is best for our democracy if the American public knows this.

\section{Shifting From Privacy to Public Policy}

I71 In the end, given that the Justices and their clerks are government employees with remarkable influence and that the American public has a strong interest in the workings of our government, privacy cannot justify the level of control the Justices have been exercising. The concept of privacy is a distraction and allows far too much idiosyncrasy. As evidenced by the Freedom of Information Act and the Presidential Records Act, ${ }^{113}$ public policy can be used to protect the deliberative processes of government for a time while still allowing for access to information

113. The Presidential Records Act has a mixed record of success and provides more loopholes and exceptions than it should, but it is an improvement on the situation regarding presidential papers that existed prior to its 1981 effective date. 
that will enlighten the public and provide accountability. As Hyman asks, "Is the United States Supreme Court so fragile or vulnerable that researchers' access to Justices' notes of conference committee proceedings will damage this vital institution? The Supreme Court is a marble palace. But it should not be and has no means to be a self-quarantined intellectual fortress." 114

\section{Proposals for Improvement}

I72 What options exist that would address these concerns?

\section{“Public Papers" as Public Property}

I73 Congress could pass a law changing the ownership of the Justices' papers as recommended by the Public Documents Commission in 1977. As described above, ${ }^{115}$ the commission recommended distinguishing three categories of records created by all federal judges, including Supreme Court Justices: federal records, public papers, and personal papers. Personal papers-those that deal with personal matters rather than work for the courts-would remain private property. Public papers-the working papers of the chambers (e.g., conference notes, memos, interand intra-chamber correspondence, opinion drafts) - would become public property subject to retention, preservation, and access requirements.

I74 The commission did recognize the interest in shielding Justices and any ongoing matters before the Court from immediate blowback, allowing for the records to be closed for up to fifteen years following the individual's retirement from the bench. ${ }^{116}$ As Kathryn Watts notes, a floor as well as a ceiling would be prudent in light of the Justices' reactions to the release of the Marshall papers, which occurred long after the commission's report. A window of no fewer than ten years and no more than twenty would allow the Justices, and others represented in the collections, a long stretch of confidentiality and would ensure that no matters discussed in the papers were still in front of the Court. After twenty years, access restrictions would be allowed only on materials the discourse of which would "constitute an unwarranted invasion of privacy." 117

I75 The commission based its fifteen-year recommendation on retirement from the bench, not death. This is the more sustainable approach from an archival standpoint because the release date is known when the collection is given rather than being indeterminate. Obviously, a Justice could die while still on the bench, as did Justice Scalia, but a release date would still be definite. The ten- to twenty-year window recommended here should be based on retirement rather than death.

I76 This first proposal faces a few very high hurdles. Congress does not seem interested in such legislation. It has ignored the Public Documents Commission's recommendations for forty years, even after the Senate revisited the matter in 1993 and reached many of the same conclusions. It would be politically difficult, to say the least, for lawmakers to pass legislation changing the ownership of judicial papers while leaving unchanged the ownership of their own papers. It would likely

114. Hyman, supra note 106 , at 10.

115. See supra II 36.

116. See Commission Final Report, supra note 21, at 41.

117. Id. 
take a Supreme Court scandal on the scale of Watergate to garner the will to make such a change happen, and the Supreme Court is largely scandal-free.

I77 It may be constitutionally difficult as well. Given the separation of powers doctrine, Congress would have to overcome questions about its constitutional ability to regulate the judicial branch of government. That said, Congress has been allowed to regulate the executive branch, but that was accomplished in the wake of Watergate. Also, the Supreme Court's interests in the disposition of presidential papers align with the interests of Congress in favor of public access. As for the Justices' papers, however, there is and has been no scandal or corruption to prompt reform, and when the Justices' confidentiality is at stake, their interests run counter to any interest the Congress has in preservation and access.

I78 Another concern is expense. Public ownership would mean taking on the full cost of retaining, preserving, processing, and storing the Justices' papers. This would be expensive. As Watts points out, a change in ownership status by law could also result in a taking. ${ }^{118}$ This could add compensation to the cost for several decades.

\section{Congress Changes Ownership Status Only; Judicial Branch Works Out Details}

I79 Professor Watts proposes that Congress pass a law changing the ownership status of the Justices' papers to public while leaving the details about preservation and access up to the judicial branch to determine for itself. This is an appealing option in that it would accomplish the underlying goal regarding ownership while not alienating the Justices nor infringing quite so far on the separation of powers doctrine. After all, Watts argues, the PRA has not been found to violate the separation of powers doctrine. ${ }^{119}$

I80 As noted above, however, when the PRA was written, the political interests of Congress and the Supreme Court were aligned in the aftermath of the Watergate scandal. In the case of the working papers of the Justices, those interests will be at odds instead. In the end, the question of the constitutionality of a statute changing the ownership status of the Justices' papers will be decided by the Supreme Court itself. The same holds for the question of whether such a law would constitute a taking. How likely is the Court to uphold such a law?

I81 Watts's proposal also does not envision any enforcement. Imagine a scenario in which a majority of the Court finds the law constitutional, but a disagreeing Justice does not wish to comply. What enforcement mechanism could we possibly want? If we could settle on a fine high enough to force compliance, would that be a positive resolution? History has already shown us that the PRA is difficult to enforce and subject to back-and-forth executive orders. ${ }^{120}$ Trying to enforce an ownership change against reluctant Justices is not going to be any easier.

118. See Watts, supra note 26, at 1714-15.

119. Watts points out the separation of powers doctrine did not stop the passage of the PRA, urging that perhaps it is less of an issue than might be presumed. Id. at 1718 .

120. See id. at 1716-17; Wendy Ginsberg, Cong. Research Serv., R40238, The Presidential ReCords ACt: BACKGROUND AND ReCENT Issues FOR CONGRESS (2014). 


\section{Incentives for Complete Collections and Short Embargos}

I82 Given the difficulties posed by the public ownership solutions, is there a more tenable alternative? A program to provide grants to support donated collections in return for shorter embargo periods may be a viable answer.

I83 When Justices select archives for their papers, they select institutions they trust to process and maintain the collection. Processing and storing a collection typical of a modern Supreme Court Justice requires significant resources on the part of the institution, which may or may not receive financial help from the family. To ease this burden and incentivize the appropriate retention of Justices' papers, Congress can establish a program to grant funds to institutions that receive a major collection of papers from a Justice. In donating his or her papers, a Justice is then giving the institution both the collection and funds to help process and store the documents.

I84 Under this scheme, the amount of the grant would depend on meeting conditions such as minimum number of linear feet and a standard of comprehensiveness. The grant should also encourage a short embargo period. For instance, a collection that is made public in ten to fifteen years after donation could result in a $\$ 1$ million grant for the repository, while a fifteen- to twenty-year embargo would result in only $\$ 500,000$. This would give institutions an incentive in advising the Justice as to the advantages of a shorter embargo and, for a Justice wanting to support the institution as well as cement a legacy, provide a tangible reason to accept. ${ }^{121}$

I85 Clearly, this niche program would be invoked rarely since there are relatively few Supreme Court Justices. In that sense, the program would be inexpensive, averaging well under $\$ 1$ million per year. Yet it would encourage Justices and institutions to move to shorter embargos and provide much-needed funding for processing the collections that are donated. The small price tag should help make it politically palatable.

I86 This proposal also eases separation of powers concerns by allowing the Justices to eschew the program entirely; participation would not be required. Instead, participation would be incentivized monetarily and, over time, through reputation. One can see a future in which a Justice who refuses the program in order to place more restrictive access requirements would seem miserly. ${ }^{122}$ It would also remove the risk of creating a situation in which a taking has occurred.

I87 The incentive-only structure would also allow members of Congress to avoid the political discomfort of regulating access to the Justices' papers while ignoring their own. In supporting this proposal, a congressperson can point to the limited number of Justices, the relative importance of their papers, and the logisti-

121. The graduated plan also acknowledges that shorter embargo periods require faster processing of the collection, which in turn requires more money.

122. See, e.g., Linda Greenhouse, Down the Memory Hole, N.Y. Times, Oct. 9, 2009, at A31; Tony Mauro, Souter Blocks Access to His Papers for 50 Years, The BLT: The Blog of LegalTimes (Aug. 26, 2009), http://legaltimes.typepad.com/blt/2009/08/souter-blocks-access-to-his-papers-for-50 -years.html [https://perma.cc/9H5U-UKR7]. Each of these articles implies or states that Justice Souter's papers will open fifty years after his retirement. It is, in fact, to be fifty years after his death. See Tony Mauro, The Long Wait for Souter's Papers, LegalTimes, Apr. 22, 2015, at 18. This has been independently confirmed by the New Hampshire Historical Society. Telephone interview with Wesley Balla, Director of Collections \& Exhibitions, N.H. Historical Soc'y (July 13, 2017). 
cal and fiscal infeasibility of a similar program to preserve the papers of the many members of Congress as reasons to leave the status of their own papers alone.

\section{Archive and Library Guidelines}

I88 Regardless of the likelihood of any of the foregoing proposals, archivists and librarians can make a difference by developing specific recommendations for judicial papers. The Library of Congress and several leading educational institutions already hold multiple collections and are likely to be asked to accept more in the future. If we, as a profession, had preservation and access guidelines specifically geared toward judicial papers, the librarians at these institutions, and smaller ones as well, could use these guidelines to urge donors to adopt more predictable timetables (e.g., retirement rather than death), a definite embargo period window (e.g., ten to twenty years), and equal access (e.g., no exclusive access to designated researchers). ${ }^{123}$

I89 We can also make such guidelines applicable beyond Supreme Court Justices. Concerns regarding preservation and access apply to other federal judges as well as to state judges, particularly state supreme court justices. The guidelines could be used to inform decisions made about collections from other public officials such as legislators, governors, and mayors. Not only would this enhance the utility of the recommendations to more libraries, but it could well result in greater adoption that would create new norms among our jurists and politicians. In short, if the Justices and other prominent public servants received the same advice from every professional librarian and archivist they talked to, we could start to change the narrative surrounding access to their papers.

\section{Conclusion}

[90 Open government advocate Steven Aftergood has written, "Ensuring appropriate public access to government information, while establishing proper boundaries around the exercise of official secrecy, has proved to be an elusive goal." 124 Although Aftergood was referring to the confidentiality system, his words apply to the Justices' papers as well. Thanks to the continuation of the private ownership model, an appropriate balance between access and secrecy has indeed eluded us. The current regime weighs more heavily toward secrecy than access even though the working papers of the Supreme Court Justices are of profound interest and importance to researchers and to the American public.

I91 Archivists and librarians have been struggling with the tension between public access and donor privacy for decades. ${ }^{125}$ The scholarship around this subject

123. The guidelines, which should mirror the suggestions made above for the incentive program, could be generalized to apply to other federal and state judges as well. Not only would this enhance their utility to more libraries, but it could well result in greater adoption that would create new norms among our jurists.

124. Aftergood, supra note 32, at 399.

125. See, e.g, Privacy and Confidentiality Perspectives (Menzi L. Behrnd-Klodt \& Peter J. Wosh eds., 2005); Marybeth Gaudette, Playing Fair with the Right to Privacy, 28 Archival Issues 21 (2003); Mark A. Greene, Moderation in Everything, Access in Nothing?: Opinions About Access Restrictions on Private Papers, 18 ARCHIVAL Issues 31 (1993); Hodson, supra note 30, at 194; Schwarz, supra note 24, at 179; Paul J. Sillitoe, Privacy in a Public Place: Managing Public Access to Personal Information Controlled by Archives Services, 19 J. Soc'y ARChivists 5 (1998). 
reveals that archivists generally try to walk a fine line between acquiescing to a donor's wishes and encouraging a donor to either (1) do more to protect the privacy of third-party authors-typically correspondents of the donor-represented in the collection or, as is the issue with Supreme Court Justices, (2) place fewer restrictions on access to facilitate research, scholarship, and public understanding. ${ }^{126}$ As long as the Justices' papers remain private property, archivists and librarians are limited to direct advocacy. We can encourage donors to provide as much access as possible within a reasonable time. We can communicate that archival professional ethics state that access should be equal for all researchers, ${ }^{127}$ and that if any part of the collection is to be restricted, it should be restricted to all researchers equally. ${ }^{128}$ We can advocate for definitive opening dates rather than restrictions of indeterminate duration. ${ }^{129}$ We can inform donors that placing onerous restrictions on an archive can lead to inequitable access, incomplete and speculative research, decoy requests, ${ }^{130}$ and inconsistencies. We can communicate that reasonable access leaves a better impression than excessive restriction.

\92 Given the importance and politicization of the Supreme Court, a Justice's service to the public does not end the moment he or she retires. Rather, it includes enabling the public to examine and understand how the Justice performed his or her duties on the Court. Most of the Justices understand this, but many of them make choices that unnecessarily restrict public access for too long. A workable resolution to the dilemma posed by a history of private ownership, a tradition of secrecy, and a need for public access is not easy to find. Librarians and archivists are well versed in these balancing acts and have much to contribute to the search for a better solution.

126. See, e.g., Panofsky \& Moir, supra note 27.

127. Danielson, supra note 29, at 60-62, discusses potential problems with open archives as they place burdens on archivists/librarians as arbiters. For example, if an archivist has open, equalaccess archives and receives help requests from both an undergraduate and a celebrated historian, to which person does the archivist give his or her limited time? Should an archivist keep materials with high scholarly value in reserve for reputable scholars and away from "hacks"? What if the library is a publisher as well? This can lead to conflicts with researchers.

128. According to the ALA-SAA Joint Statement on Access to Research Materials in Archives and Special Collections Libraries,

It is the responsibility of a repository (1) to make available original research materials (2) in its possession on equal terms of access. ... A repository should not deny any researcher access to materials, nor grant privileged or exclusive use of materials to any researcher, nor conceal the existence of any body of materials from any researcher, unless required to do so by law, institutional access policy, or donor or purchase stipulation. ... Repositories must be committed to preserving research materials and to making them available for research as quickly as practical following their acquisition.

ALA/SAA Joint Statement on Access to Research Materials in Archives and Special Collections Libraries, Soc'y of Am. Archivists (June 1, 2009), https://www2.archivists.org/statements/alasaa-joint -statement-on-access-to-research-materials-in-archives-and-special-collection [https://perma.cc/PY6U -UAP2].

129. Heather MacNeil, Information Privacy, Liberty, and Democracy, in PRIVACY AND ConFidentiality Perspectives, supra note 30, at 67, 78-79.

130. Decoy requests occur when a scholar likely to be granted access requests materials but is secretly doing so on behalf of someone who would not have been given access on his or her own merit. See Danielson, supra note 29, at 57. 


\section{Appendix}

\section{Donations and Access Restrictions on Most Significant Collection of Papers for Justices Serving on the Court During and Since 1900}

Notes: In almost all cases, the largest collection was selected for this line of inquiry. Exceptions were made if a smaller collection held material relevant to the Justice's time on the Court or if two collections were equally important. In many instances, the actual papers have been filmed, and access is granted to microform only. The concern in this instance is access to the content, rather than a particular format, so this restriction to microfilm is not noted.

\section{Justice \\ Supreme Court Tenure \\ Disposition of Judicial Papers}

John Marshall Harlan

1877-1911

Horace Gray

$1881-1902$
Justice Harlan's papers were donated to the Library of Congress without restrictions in 1958, forty-seven years after he left the Court in 1911.

Originals of Justice Gray's papers, which consist mostly of congratulatory letters, were donated by his family to the Supreme Court Library in 1948, forty-six years after Justice Gray died while still serving on the Court. The papers are now held by the Supreme Court curator. There were no restrictions on the donation.

Microform copies were made for the Library of Congress in the early 1950 s and have been available to researchers since that time.

\begin{tabular}{|c|c|c|}
\hline Melville Weston Fuller & $1888-1910$ & $\begin{array}{l}\text { Chief Justice Fuller's papers were donated to the } \\
\text { Library of Congress without restriction in } 1978 \text {, sixty- } \\
\text { eight years after Chief Justice Fuller left the Court in } \\
1910 .\end{array}$ \\
\hline David Josiah Brewer & $1889-1910$ & $\begin{array}{l}\text { Yale University Sterling Memorial Library holds the } \\
\text { Brewer Family papers, which were donated by family } \\
\text { members between } 1951 \text { and } 1965 \text {, more than forty } \\
\text { years after his time on the Court ended. It appears } \\
\text { that no restrictions were ever placed on the donation. }\end{array}$ \\
\hline Henry Billings Brown & $1890-1906$ & $\begin{array}{l}\text { Detroit Public Library holds Justice Brown's collection, } \\
\text { which came from various donors with no restrictions. }\end{array}$ \\
\hline George Shiras, Jr. & $1892-1903$ & $\begin{array}{l}\text { If any of Justice Shiras's papers are still in existence, } \\
\text { they are thought to be in the hands of his heirs. }\end{array}$ \\
\hline Rufus Wheeler Peckham & $1895-1909$ & $\begin{array}{l}\text { Justice Peckham's papers are in the Wheeler H. Peck- } \\
\text { ham archive at the Library of Congress. Very few deal } \\
\text { with his time on the Supreme Court. The collection } \\
\text { was donated in 1967, fifty-eight years after Peckham } \\
\text { left the Court, with no restrictions. }\end{array}$ \\
\hline Joseph McKenna & $1898-1925$ & $\begin{array}{l}\text { Justice McKenna's papers were destroyed. The few } \\
\text { that may remain are thought to be in the hands of his } \\
\text { heirs. }\end{array}$ \\
\hline $\begin{array}{l}\text { Oliver Wendell Holmes, } \\
\text { Jr. }\end{array}$ & $1902-1932$ & $\begin{array}{l}\text { The bulk of the Oliver Wendell Holmes papers were } \\
\text { donated to Harvard Law School in } 1948 \text { by Methyl } \\
\text { Palfrey, wife of Holmes's executor, John G. Palfrey. } \\
\text { This donation came sixteen years after Justice Holmes } \\
\text { retired from the Court. Harvard Law received addi- } \\
\text { tional donations of Holmes's papers and related } \\
\text { materials from other donors. }\end{array}$ \\
\hline William Rufus Day & $1903-1922$ & $\begin{array}{l}\text { Justice Day donated his papers to the Library of } \\
\text { Congress in } 1960 \text {, thirty-eight years after he left the } \\
\text { Court, with no restrictions. }\end{array}$ \\
\hline
\end{tabular}




\section{Justice $\quad$ Supreme Court Tenure $\quad$ Disposition of Judicial Papers}

William Henry Moody

$1906-1910$
The Library of Congress purchased two collections of letters written by Justice Moody, who retired from the Court in 1910. These purchases occurred in 1936 and 1952. No restrictions were placed on these accessions.

\begin{tabular}{|c|c|c|}
\hline Horace Harmon Lurton & 1909-1914 & $\begin{array}{l}\text { Justice Lurton's papers were donated to the Library } \\
\text { of Congress in 1957, forty-three years after he left the } \\
\text { Court, with no restrictions. }\end{array}$ \\
\hline
\end{tabular}

Charles Evans Hughes 1910-1941 Early deposits of papers in the Library of Congress occurred in 1933-1934. The bulk of the collection was deposited in the Library of Congress in 1941; access was restricted to those given Hughes's written permission. This collection and additional papers were gifted to the library in 1951, but access remained restricted to family members and assignees for twenty-five years or until all those designated as such died. However, the family released all restrictions on the papers in 1974 .

\begin{tabular}{ll}
\hline Joseph Rucker Lamar & University of Georgia received Justice Lamar's papers \\
& as a gift from Lamar's wife in 1938, twenty-two years \\
& after Lamar's service on the Court ended, with no \\
& restrictions.
\end{tabular}

Willis Van Devanter $\quad$ 1910-1937 Papers were first deposited with the Library of Con-
gress in 1960, twenty-three years after Van Devanter left the Court. Van Devanter died in 1941, so the donor was likely a family member. The papers were restricted for ten years or until the donor's death, though access could be granted upon request. The papers were thus unrestricted by 1970 , thirty-three years after Van Devanter left the Court. The papers were then gifted to the Library of Congress in 1980 and remain free of access restrictions.

\begin{tabular}{|c|c|c|}
\hline Edward Douglass White & $1910-1921$ & $\begin{array}{l}\text { Chief Justice White's papers were destroyed. Three } \\
\text { items are at Louisiana State University. }\end{array}$ \\
\hline
\end{tabular}

Mahlon Pitney $\quad$ 1912-1922 Pitney's papers from his time at the Court are thought
to have been destroyed. The Pitney family papers are held at the New Jersey Historical Society but are not particularly relevant to Justice Pitney's service on the Court.

James Clark McReynolds $\quad$ 1914-1941

Papers were given to the University of Virginia Alderman Library (later transferred to the university's Arthur J. Morris Law Library) in the early 1950 s by Justice McReynolds's nephew. Correspondence between Justice McReynolds and his brother was restricted for at least ten years, and longer if the "contemporaries" were still living, as it was deemed too personal for contemporaneous public scrutiny.

Louis Dembitz Brandeis 1916-1939
Many of Justice Brandeis's papers were given to the University of Louisville. There is some indication that these papers (or perhaps only those given after Brandeis's death in 1941) were closed during the lifetime of Bernard Flexner, a friend of Brandeis who made arrangements for Brandeis's donation with the university. Flexner died in 1945, six years after Brandeis left the Court. 


\section{Justice}

John Hessin Clarke

Supreme Court Tenure

$1916-1922$

William Howard Taft

$1921-1930$

\section{Disposition of Judicial Papers}

Papers were bequeathed to Case Western Reserve University in Justice Clarke's will with no restrictions.

Deposit of the Taft papers with the Library of Congress began in 1919, several years after the end of his presidency. Further papers were deposited over the next fifteen years, and smaller deposits came later. Early access was allowed only by permission. The papers were then gifted to the library in 1952, although access was restricted to family and researchers receiving family permission until 1960 at the latest (restrictions could be relaxed earlier if the family so chose or if the donating family members died).

\begin{tabular}{|c|c|c|}
\hline Pierce Butler & 1922-1939 & $\begin{array}{l}\text { Justice Butler's papers are part of the Butler family } \\
\text { collection at the Minnesota Historical Society. The } \\
\text { collection was donated in the early } 1990 \text { s by a family } \\
\text { member. The papers will remain closed, except by } \\
\text { permission of a named descendant of the donor, until } \\
\text { seven years after the death of this named descen- } \\
\text { dant. The named descendant is to appoint a proxy for } \\
\text { granting permission in the seven-year period follow- } \\
\text { ing the descendant's death. }\end{array}$ \\
\hline George Sutherland & $1922-1938$ & $\begin{array}{l}\text { The Sutherland papers were donated to the Library } \\
\text { of Congress without restriction in 1959, twenty-one } \\
\text { years after he left the Court. }\end{array}$ \\
\hline Edward Terry Sanford & $1923-1930$ & $\begin{array}{l}\text { Justice Sanford's papers were given to the University } \\
\text { of Tennessee (originally given to the Law Library, but } \\
\text { now held in Special Collections) prior to } 1960 \text { (how } \\
\text { much prior is unknown) by a descendant of Justice } \\
\text { Sanford. There were no restrictions, but the donor did } \\
\text { reserve the right to reclaim anything from the collec- } \\
\text { tion. }\end{array}$ \\
\hline Harlan Fiske Stone & $1925-1946$ & $\begin{array}{l}\text { Chief Justice Stone's papers were given to the Library } \\
\text { of Congress in 1949, but were not processed until } \\
1975 . \text { Presumably, they were effectively unavailable } \\
\text { for those twenty-six years, but were then without } \\
\text { restriction. }\end{array}$ \\
\hline Owen Josephus Roberts & $1930-1945$ & $\begin{array}{l}\text { Justice Roberts's judicial papers were destroyed. The } \\
\text { Library of Congress holds a small collection of corre- } \\
\text { spondence related to his appointment that has never } \\
\text { been restricted. }\end{array}$ \\
\hline $\begin{array}{l}\text { Benjamin Nathan } \\
\text { Cardozo }\end{array}$ & $1932-1938$ & $\begin{array}{l}\text { Justice Cardozo's papers were bequeathed to Colum- } \\
\text { bia University with no restrictions. However, accord- } \\
\text { ing to the National Study Commission Final Report, } \\
\text { most of Cardozo's Supreme Court working papers } \\
\text { were destroyed. }\end{array}$ \\
\hline
\end{tabular}




\section{Justice}

Supreme Court Tenure
1937-1971
Disposition of Judicial Papers

Justice Black's conference notes were allegedly destroyed. The Library of Congress holds other Black papers, a gift made in 1973. A ten-year restriction was imposed on non-Supreme Court papers, with exceptions for family and those with permission. Access to Supreme Court files was to be restricted until the retirement or death (whichever came first) of all those who participated in the case or were active members of the Court at the time of the decision. The family decided to start taking requests for access from the public in 1985. In 2004, thirty-three years after Justice Black's death and departure from the Court, the collection became available without restrictions (with the exception of a single letter).

Stanley Forman Reed 1938-1957 Justice Reed's papers were given to the University of Kentucky. Nothing was to be released and no publicity allowed until cataloging was complete and a review conducted by the Reed family. Documents relating to specific Supreme Court decisions were not released until all members of the Court at the time of decision died; the last of these would have been Justice Brennan, who died in 1997, forty years after Justice Reed's time on the Court ended. Documents relating to any specific individual on the Court were not released until the death of that individual. Documents embarrassing to Justice Reed or his family can be withdrawn.

William Orville Douglas 1939-1975

Justice Douglas's papers were deposited with the Library of Congress beginning in 1960 . This collection was restricted during his lifetime to those granted permission by Douglas only. When he died in 1980 , the collection converted to a gift and was opened to the public. Further Douglas papers arrived after his death. These were restricted for five years and then opened to researchers in May 1985, with the exception of three boxes that remain closed by request of the donor and some material deemed confidential under federal rules.

\author{
Felix Frankfurter
}

$1939-1962$
Justice Frankfurter's non-Supreme Court papers were given to the Library of Congress in 1955 with the restriction that no item would be released until sixteen years after the date it was created. This was later changed to a restriction that expired upon Frankfurter's death, which occurred in 1965.

Harvard holds Justice Frankfurter's Supreme Court papers under a bequest in his will, though the bulk of the papers were received in 1962, prior to his death. Smaller portions of the papers came later. They were originally closed except to scholars who were given specific permission from a two- to three-person review board composed of friends/colleagues of Frankfurter (this restriction seems to have been created by Harvard Law School personnel and Frankfurter's longtime secretary rather than in the deed of gift). It is not known exactly when this review board requirement ended, but probably no later than 1992 when Professor Paul Freund, one of the reviewers, died. 
Frank Murphy

1940-1949

The bulk of Justice Murphy's papers were gifted to the University of Michigan by the Justice's brother in 1961 and 1965 . Additions from other sources were acquired throughout the 1960s. By stipulation of the donor, access was, and still is, restricted to "bona fide scholars" who must sign a contract regarding appropriate use of the papers. Researchers without a Ph.D. must justify their need for the papers, provide references from professors, and be granted approval by the director of the university's Bentley Historical Library.

\begin{tabular}{lll}
\hline James Francis Byrnes & 1941-1942 & $\begin{array}{l}\text { The Byrnes papers were given to Clemson Univer- } \\
\text { sity between } 1962 \text { and 1981. No restrictions were } \\
\text { attached. }\end{array}$ \\
\hline $\begin{array}{l}\text { Robert Houghwout } \\
\text { Jackson }\end{array}$ & $\begin{array}{l}\text { Justice Jackson's papers were in the possession of a } \\
\text { single scholar with absolute discretion over access } \\
\text { following Jackson's death. The family then donated } \\
\text { the papers to the Library of Congress in 1985, thirty- } \\
\text { one years after Jackson's death. }\end{array}$ \\
\hline
\end{tabular}

\begin{tabular}{ll}
\hline Wiley Blount Rutledge $\quad$ 1943-1949 & $\begin{array}{l}\text { The Rutledge papers were given to the Library of Con- } \\
\text { gress in 1980, thirty-one years after his death ended } \\
\text { his tenure on the Court. They were immediately avail- } \\
\text { able without restriction. }\end{array}$ \\
\hline
\end{tabular}

Harold Hitz Burton 1945-1958 Justice Burton's papers were given to the Library of Congress in 1959 and restricted to Burton himself and those with his express permission until his death in 1964. This changed in 1965 when a second round of papers was added to the collection. A few items were restricted to Burton's two sons for twenty-five years (1980) or until the death of their mother, whichever came first. Mrs. Burton died in 1970, and the collection was opened fully at that time.

Frederick Moore Vinson Chief Justice Vinson's papers were given to the University of Kentucky. His Supreme Court files remained closed, except by permission from the family, until after the deaths of Justices Tom C. Clark, William 0. Douglas, and Stanley F. Reed. This occurred in 1980, twenty-seven years after Vinson's death ended his tenure on the Court.

Tom Campbell Clark 1949-1967 Justice Clark's papers were given to the University of
Texas Tarlton Law Library by his wife in 1977 with no restrictions. This meant a delay of only ten years.

Sherman Minton

$1949-1956$ Justice Minton's papers were given to the Harry S. Truman Library in 1957 and 1959 with instructions that the U.S. Archivist was to review and seal all items relating to (1) private and family business of Minton or his correspondents, (2) investigations or appointments of individuals, (3) statements made in confidence, and (4) anything else that might be used to harass or damage any living person. Sealed items were to be reviewed from time to time to determine whether restriction was no longer required. Access is now open.

According to the National Study Commission, most of Justice Minton's Supreme Court working papers were destroyed. 


\section{Justice Supreme Court Tenure Disposition of Judicial Papers}

Earl Warren

$1953-1969$

The Warren papers were placed in the Library of Congress in 1969 and restricted to those with Warren's permission or that of an assignee until 1985 . Access has been unrestricted since January 1985 , sixteen years after his retirement. Some non-Supreme Court papers remain classified.

John Marshall Harlan II 1955-1971 Justice Harlan's papers were given to Princeton University in 1972 and 1974. They were restricted from all use except by permission of Harlan's daughter until July 8,1979 , with a possible one-year extension of the restriction. Financial records in the collection were closed until July 8, 1982.

Later correspondence suggests that the family inquired about extending the restriction on case files for cases "handled during the period present members were sitting on the Court," but there is no indication in the archival records as to whether this was actually done.

William Joseph 1956-1990

Brennan, Jr.

Brennan began giving his papers to the Library of Congress in 1967, and his access restrictions were complicated. Case histories and legal files were to be closed until three years after Brennan's death or the death of the last surviving Justice involved in the case/decision, whichever came later, but not to exceed fifteen years after Brennan's death. Correspondence was to open twenty years after his death. Upon Brennan's death in 1997, it was determined that case histories and some post-1985 case files would remain closed until July 24,2000 , three years after his death. His correspondence opened on July 24 , 2017, twenty years after his death.

\begin{tabular}{lll}
\hline Charles Evans Whittaker & $1957-1962$ & Disposition unknown. \\
\hline Potter Stewart & $1958-1981$ & Yale University holds the Potter Stewart papers. They
\end{tabular}
were restricted until all members who served with Stewart retired. Justice Stevens was the last of these, thus the Stewart papers opened in 2010, twenty-nine years after he left the Court.

Arthur Joseph Goldberg 1962-1965 Both Northwestern University and the Library of Congress now have substantial collections of Justice Goldberg's papers, but they had been in Goldberg's possession for more than twenty years after he left the Court in 1965. The agreement giving the papers to the Library of Congress was signed in 1988, with additional accessions between 1992 and 2002 following Goldberg's death in 1990. None of these gifts were ever restricted, but because the gifts came so long after his time on the Court, his papers were effectively unavailable for research for twenty-five years or more.

The collection at Northwestern University was donated in 1996 by the Justice's children. Evidence indicates that it was also given without any restrictions. 


\section{Justice}

Byron Raymond White

1962-1993
Supreme Court Tenure

\section{Disposition of Judicial Papers}

The Library of Congress was gifted Justice White's papers in 1988 with access restricted to White alone. The papers were then to remain completely closed for ten years after his death, which occurred in 2002. The collection opened in 2012, nineteen years after his retirement.

Abe Fortas 1965-1969

Justice Fortas's papers were given to Yale University's Sterling Memorial Library by Fortas in 1974 and Carolyn E. Agger Fortas in 1988 and 1991. These papers were closed to researchers until 2000, thirty-one years after his retirement, except with the written authorization of the donor or donor's designee. On January 1, 2000, the papers were opened to researchers.

An anonymous donor made a further contribution in 2012.

Thurgood Marshall 1967-1991 Justice Marshall's papers are held at Library of Congress. They were closed during Marshall's lifetime but opened shortly after his death. The deed of gift used the language "at the discretion of the Library"; conversations between the Librarian of Congress and Justice Marshall indicated that the Justice wanted no moratorium.

\begin{tabular}{|c|c|c|}
\hline Warren Earl Burger & $1969-1986$ & $\begin{array}{l}\text { William \& Mary Law Library holds the Burger papers. } \\
\text { They are closed until } 2026 \text {, forty years after his retire- } \\
\text { ment, as instructed in the deed of gift. }\end{array}$ \\
\hline Harry Andrew Blackmun & 1970-1994 & $\begin{array}{l}\text { Justice Blackmun donated his papers to the the } \\
\text { Library of Congress in } 1997 \text { with access restricted to } \\
\text { Blackmun and those obtaining his permission. Upon } \\
\text { his death in 1999, the duty to grant permission passed } \\
\text { to an assignee for five years. The collection opened for } \\
\text { public research without restriction in } 2004 \text {. Although } \\
\text { this resulted in a delay of only ten years, this was not } \\
\text { a foregone conclusion since the time period depended } \\
\text { on the date of Justice Blackmun's death. }\end{array}$ \\
\hline
\end{tabular}

Lewis Franklin Powell, Jr. 1972-1987 Justice Powell's papers are held by Washington \& Lee University's School of Law. Powell's Supreme Court files were closed, except by permission, until all members who served with the Justice left the bench. Justice Scalia, who died in 2016, was the last of these, so Justice Powell's Supreme Court files opened twenty-nine years after his retirement.

William Hubbs Rehnquist 1972-2005 Chief Justice Rehnquist's papers are held at the Hoover Institute. His Supreme Court papers are opening on a rolling basis as his colleagues on the Court die. They are currently closed from 1975 on, as Justice Stevens joined the Court in 1975. Upon Stevens's passing, Rehnquist's papers through September 1981, when Justice O'Connor joined the Court, will open.

\begin{tabular}{ll}
\hline John Paul Stevens & Justice Stevens's papers are held at the Library of \\
& Congress and are currently restricted. Access to mate- \\
& rials predating October 1, 2005, will open in October \\
& 2020. Materials from after October 1, 2005, will \\
remain closed until 2030.
\end{tabular}




\section{Justice}

Supreme Court Tenure

Sandra Day O’Connor
$1981-2006$

Disposition of Judicial Papers

Justice O'Connor's papers are, or will be, held at the Library of Congress. All case files are closed until all members who served with her have retired from the bench (no rolling opening). Still to retire are Justices Kennedy, Thomas, Ginsburg, Breyer, and Chief Justice Roberts.

\begin{tabular}{ll}
\hline Antonin Scalia & Justice Scalia's papers have been donated to Harvard \\
& Law Library. They are completely closed until 2020, at \\
& which time pre-judicial and general papers will open.
\end{tabular}
After 2020 , case files will open on a rolling basis as those who served on the bench with Scalia die.

Anthony McLeod 1988-2018 Disposition unknown
Kennedy

David Hackett Souter 1990-2009 Justice Souter donated his papers to the New Hamp-
shire Historical Society. They will remain closed until fifty years after Souter's death (which means at least 2068 as Souter is still alive at the time of publication in 2018).

\begin{tabular}{|c|c|c|}
\hline Clarence Thomas & 1991- & Disposition unknown \\
\hline Ruth Bader Ginsburg & 1993- & $\begin{array}{l}\text { Justice Ginsburg's papers are, or will be, at the } \\
\text { Library of Congress. Justice Ginsburg is already tak- } \\
\text { ing requests for materials from before her service on } \\
\text { the federal bench. Nothing is publically known about } \\
\text { future access to her judicial papers other than that } \\
\text { they will be accessible at some point. }\end{array}$ \\
\hline
\end{tabular}

\begin{tabular}{lll}
\hline Stephen Gerald Breyer & $1994^{-}$ & Disposition unknown \\
\hline John Glover Roberts, Jr. & $2005^{-}$ & Disposition unknown \\
\hline Samuel Anthony Alito, Jr. & $2006-$ & Disposition unknown \\
\hline Sonia Maria Sotomayor & $2009-$ & Disposition unknown \\
\hline Elena Kagan & $2010-$ & Disposition unknown \\
\hline Neil McGill Gorsuch & $2017-$ & Disposition unknown \\
\hline
\end{tabular}

